\title{
Evaluating landfill aftercare strategies: a life cycle assessment approach*
}

David A Turner ${ }^{\mathrm{ab}}$, Richard P Beaven ${ }^{\mathrm{a}}$, \& Nick D Woodman ${ }^{\mathrm{a}}$

${ }^{a}$ Faculty of Engineering \& the Environment, University of Southampton, Highfield, Southampton, Hampshire, SO17 1BJ, UK

${ }^{\mathrm{b}}$ Technology and Society Lab, Empa, Lerchenfeldstrasse 5, 9014 St. Gallen, Switzerland

Corresponding author:

David A Turner

Tel: (+41) 587657258

Email: david.turner@empa.ch

Mailing address: Technology and Society Lab, Empa, Lerchenfeldstrasse 5, 9014 St. Gallen, Switzerland

\footnotetext{
*NOTICE: this is the authors' version of a work that was accepted for publication in Waste Management. Changes resulting from the publishing process, such as peer review, editing, corrections, structural formatting, and other quality control mechanisms may not be reflected in this document. Changes may have been made to this work since it was submitted for publication. A definitive version was subsequently published in Waste Management http://dx.doi.org/10.1016/j.wasman.2016.12.005
} 
Abstract. This study investigates the potential impacts caused by the loss of active environmental control measures during the aftercare period of landfill management. A combined mechanistic solute flow model and life cycle assessment (LCA) approach was used to evaluate the potential impacts of leachate emissions over a 10,000 year time horizon. A continuum of control loss possibilities occurring at different times and for different durations were investigated for four different basic aftercare scenarios, including a typical aftercare scenario involving a low permeability cap and three accelerated aftercare scenarios involving higher initial infiltration rates. Assuming a 'best case' where control is never lost, the largest potential impacts resulted from the typical aftercare scenario. The maximum difference between potential impacts from the 'best case' and the 'worst case', where control fails at the earliest possible point and is never reinstated, was only a fourfold increase. This highlights potential deficiencies in standard life cycle impact assessment practice, which are discussed. Nevertheless, the results show how the influence of active control loss on the potential impacts of landfilling varies considerably depending on the aftercare strategy used and highlight the importance that leachate treatment efficiencies have upon impacts.

Keywords. Life cycle assessment, landfill, aftercare, sustainability, leachate

Funding. This research was financially supported by the UK Engineering and Physical Sciences Research Council (EPSRC) [Grant EP/I012206/1]. 


\section{Introduction}

Landfilling has historically been the predominant disposal method for mixed municipal solid waste (MSW) (e.g. Hoornweg and Bhada-Tata, 2012) and in many countries is likely to remain so for the foreseeable future. Landfills often pose a significant pollution risk and contribute to a range of potential environmental and human health impacts via gaseous and liquid (leachate) pathways if not properly managed (Christensen et al., 2011). These impacts must be controlled both during the operational phase of a landfill, and post-closure (known as the 'aftercare' period) until they no longer pose an unacceptable risk to the environment.

To counter this pollution risk, modern landfills have been developed over the past few decades into highly engineered containment facilities with a focus on low-permeability capping and multi-barrier artificial lining systems that act to contain and facilitate the collection of leachate and gas produced during the degradation of landfilled waste. However, low infiltration rates caused by low permeability capping impair the degradation of organic matter and result in slow flushing rates of leachate pollutants (e.g. Beaven et al., 2014). This leads to extended aftercare timescales of hundreds, if not thousands, of years before landfills reach a point where no further management or monitoring of emissions is required (Knox, 1990; Knox et al., 2005) - a point commonly known as 'Final Storage Quality' (FSQ) or 'Completion'. A lack of certainty in funding of long-term landfill aftercare leads to an increased risk that active environmental control systems (e.g. leachate pumping/removal and treatment) are shut down or fail (henceforth, 'active control loss') prior to the achievement of FSQ, which may result in potentially significant environmental impacts.

A variety of different approaches are used for the long-term management of landfills (Laner et al., 2012), although real-world examples of practices that reduce the timescale of aftercare are limited. One of the easiest actions that an operator can take to reduce these timescales is to not utilise a low permeability cap, thereby allowing a higher flux of water to enter a site. Perhaps uniquely, based on Rowe (1991) landfill regulations in Ottawa, Canada require the installation of top covers that allow $>150 \mathrm{~mm}$ infiltration per year (Ministry of the Environment, 2008). More active measures to promote the addition of moisture to the waste mass involve the controlled addition of recirculated leachate or liquids from other sources, such as freshwater or wastewater effluent. Increasing the landfill moisture content has been shown to enhance biodegradation processes in landfills (e.g. Burton et al., 2004; Pommier et al., 2007; Meima et al., 2008) and promote organic waste stabilisation, and is at the core of landfill bioreactor technology as adopted, for example, in the USA (e.g. Townsend et al., 1996; Barlaz et al., 2010). Some researchers (e.g. Scharff et al., 2011; Beaven et al., 2014) are therefore encouraging landfill operators to implement such techniques as they may help to alleviate the burden of pollution control on future generations and, considering the uncertainties concerning aftercare funding, minimise the potential environmental impacts of possible active control loss. To this end, the first international field scale accelerated completion trial is due to start in the Netherlands in 2016 (Kattenberg et al., 2013). 
Life cycle assessment (LCA) is a systematic tool for quantitatively evaluating the potential environmental and human health impacts of products, processes, and systems over their full life cycle. LCA has become one of the principal decision support tools across all levels of waste management (Thomas and McDougall, 2005) and has been extensively applied to evaluate the potential environmental impacts of landfilling (e.g. Damgaard et al., 2011; Xing et al., 2013; Turner et al., 2016). The majority of these studies have relied on the use of waste-specific LCA models (e.g. EASETECH or WRATE). Such models, which are numerous and diverse (see Winkler and Bilitewski, 2007; Gentil et al., 2010), typically comprise a suite of linkable treatment process models. With regards to landfill modelling, waste LCA models generally adopt simplified approaches that, although suitable for modelling the potential impacts of landfill in the context of integrated waste management systems, are unable to model active control loss or deterioration of engineering systems.

A key issue that must be addressed in LCA studies of landfills is that of sustainability. As leachate emissions occur over extended time periods, they represent an uncertain risk and a burden to future generations. This contradicts one of the core principles of sustainable development, namely that the problems of today should not be passed on to future generations (United Nations, 1987). Furthermore, it is broadly recognised that the efficacy of landfill engineering systems will deteriorate in the long term (Drury et al., 2003; Rowe, 2005). The deterioration or failure/shut down of these control systems may increase the impact on future generations through the release of untreated leachates and landfill gases into the natural environment. Despite this, no previous LCA studies of landfills have considered the potential effect of active control loss on the overall impacts of landfill.

Within this context, the aim of this paper is to present a LCA approach for assessing the potential impacts of alternative landfill aftercare strategies. The model only addresses impacts through the aqueous environment, and does not consider gas emissions, although a future version could do so in principle. A simple mechanistic model for water flow and solute movement is applied to the question: When and for how long does an absence of active control (i.e. managed aftercare) result in a significant increase in the environmental impact of a site (due to liquid contaminants)? This is the first LCA study to consider the effect of active control loss on the potential impacts of landfilling.

\section{Methods}

An integrated landfill process LCA model and simple mechanistic water flow and solute movement model that is capable of simulating active control loss and deterioration of engineering systems was developed for this study. An overview of the mechanistic model is provided in Figure 1 and described further in Section 2.2. Figure 2 illustrates how the mechanistic model is integrated with LCA, which was performed in accordance with the ISO 14040 and 14044 standards (ISO, 2006a, 2006b). According to this framework, an LCA consists of four phases: (1) goal and scope definition; (2) inventory analysis; (3) impact assessment; and (4) interpretation (i.e. presentation and discussion of results). 


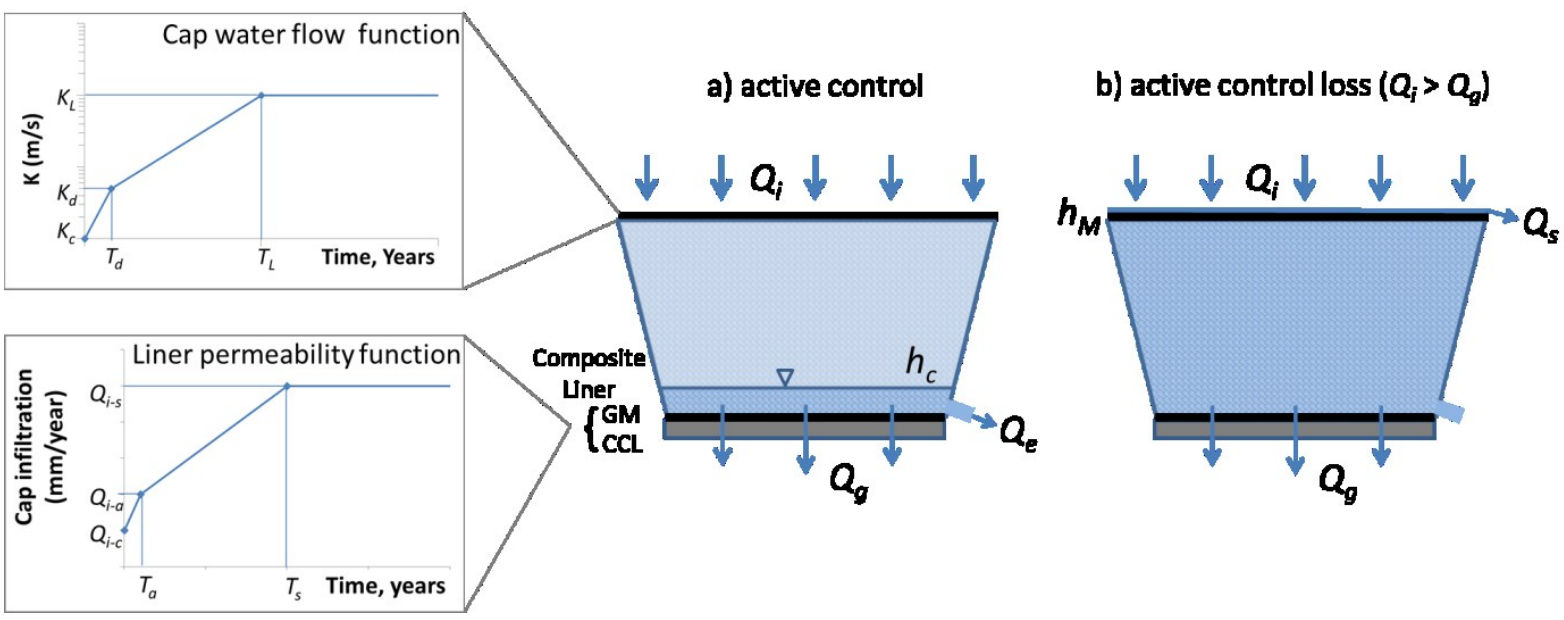

Figure 1. Schematic of the mechanistic model under conditions of a) active control (i.e. leachate is being collected and removed to treatment), and b) active control loss (i.e. leachate is not removed to treatment) where infiltration through cap $\left(Q_{i}\right)>$ flow through liner $\left(Q_{g}\right)$ and the leachate level has reached the top of landfill $\left(h_{M},\right)$ resulting in discharge to surface water $\left(Q_{s}\right)$.

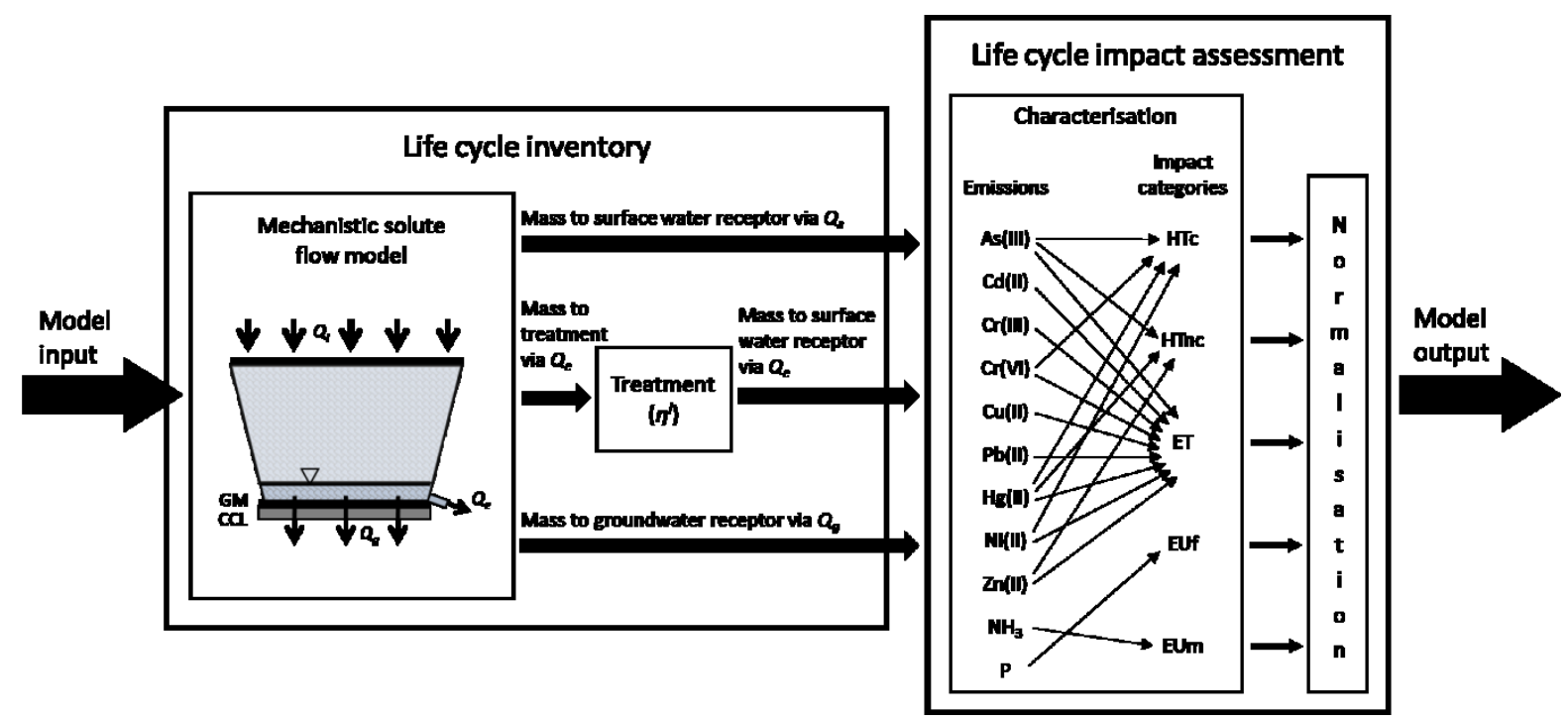

Figure 2. Schematic of integrated mechanistic water flow and solute movement model and life cycle assessment approach.

HTc, carcinogenic human toxicity; HTnc, non-carcinogenic human toxicity; ET, ecotoxicity; EUf, freshwater eutrophication; EUm, marine eutrophication.

\subsection{Goal and scope definition}

The goal of the study was to evaluate the potential impacts of leachate emissions from landfill sites operated with different aftercare strategies, taking into account the effects of potential active control loss. The purpose of the work was twofold: 1) to investigate whether LCA can be used to improve our understanding of the long term impacts of landfilling and 2) to develop an understanding of the potential effects of active control loss on these impacts. The primary audience includes landfill operators and waste regulators in the UK and abroad, as well as the landfill and LCA research communities. 
The 'functional unit' was defined as the total amount of leachate generated over a 10,000 year time horizon from a completed landfill site with a surface area of $10,000 \mathrm{~m}^{2}$ and a depth of $20 \mathrm{~m}$, filled with non-hazardous MSW. These dimensions were selected as they represent a typical landfill cell in the UK. The 10,000 year time horizon was selected to ensure that virtually all emissions from the landfill would be accounted.

The spatial boundary of the system was defined by the boundary of the landfill site, as illustrated in Figure 1. The 'zero burden assumption' was adopted, whereby environmental impacts from upstream life cycle stages prior to the deposition of waste in the landfill cell were not included (Ekvall et al., 2007). Processes included in the assessed system comprise the generation, movement, and collection of leachate at the site and the treatment of collected leachate. The following processes were excluded:

- Infrastructure, energy, and material use

- Waste transportation

- Landfill gas generation, collection, and utilisation

\subsection{Mechanistic flow and transport model}

A simple mechanistic flow and mass transport model was used to compile the life cycle inventory of emissions to the environment.

The landfill, parameterised to represent the hypothetical behaviour of a modern engineered landfill in the UK, is simplified as one-dimensional and is modelled from the time at which waste disposal is completed and the site is capped. Water enters the landfill (of depth $h_{M}$ ) at the top, by passing though the cap and entering the waste. The leachate is contained at the base by a hybrid liner - geomembrane (GM) above a compacted clay layer (CCL). The liner is overlain by a drainage layer that, when functioning, allows the leachate to be removed to a control level above the base of the site $\left(h_{c}\right)$. The leachate level in the waste is assumed to change instantaneously depending on the balance between water entering via the cap and leachate removed via the drainage layer and/or by leakage through the liner. The rate of change in leachate levels is related to the drainable (and fillable) porosity $\left(\theta_{d}\right)$ of waste, whose water content is assumed never to fall below 'field capacity'.

\subsubsection{Cap infiltration}

Cap infiltration was modelled based on the performance of a typical flexible membrane liner (FML), as described by Drury et al. (2003). Details of the values assigned to the parameters used to model cap infiltration are provided in Table 1. The infiltration into the waste is via downward flow through the cap $\left(Q_{i}\right)$, which is assumed to be a piecewise linear function.

As the cap degrades, it is assumed that the flow through the cap increases linearly over time from an initial rate, $Q_{i-c}$. Short-term variations in flow (for instance following a rainfall event) are not simulated. At the end of the 'active aftercare operations' period ( $T_{a}$ - here 
assumed to be 30 years) the cap flow is assumed to have increased to $Q_{i-a}$ due to some deterioration: it is assumed that the operator would repair any major breaches to the integrity of the cap during this period. Finally, at the end of the cap's service life $\left(T_{s}\right)$ the flow through the cap is assumed to be equal to effective precipitation $\left(Q_{i-s}\right)$. To model accelerated leachate flushing through moisture addition, the performance of the cap is overridden by a "managed" flushing rate.

Table 1. Default parameter values assigned to model the performance of the cap.

\begin{tabular}{|c|c|c|c|c|}
\hline Parameter & Notation & Unit & Value & Justification \\
\hline Infiltration through cap & $Q_{i}$ & $\mathrm{~mm} /$ year & - & \\
\hline Initial flow through cap & $Q_{i-c}$ & $\mathrm{~mm} /$ year & 50 & $\begin{array}{l}\text { Based on Golder Associates (2008) } \\
\text { and Hall et al. (2006b) }\end{array}$ \\
\hline $\begin{array}{l}\text { Flow through cap at end of 'active } \\
\text { aftercare period' }\end{array}$ & $Q_{i-a}$ & $\mathrm{~mm} /$ year & 60 & $\begin{array}{l}\text { LandSim software (See } 2.2 .4 \text { ) default } \\
\text { value representing cap performance } \\
\text { following physical and chemical } \\
\text { decline }\end{array}$ \\
\hline $\begin{array}{l}\text { Flow after cap has reached end of } \\
\text { service life }\end{array}$ & $Q_{i-s}$ & $\mathrm{~mm} /$ year & 250 & $\begin{array}{l}\text { LandSim default representing effective } \\
\text { precipitation for Eastern England }\end{array}$ \\
\hline $\begin{array}{l}\text { Time at end of 'active aftercare } \\
\text { operations period' }\end{array}$ & $T_{a}$ & years & 30 & $\begin{array}{l}\text { Based on the minimum time for } \\
\text { financial provision under Directive } \\
\text { 1999/31/EC (European Commission, } \\
\text { 1999) }\end{array}$ \\
\hline Time at end of cap 'service life' & $T_{S}$ & years & 1,000 & LandSim default (Drury et al., 2003;) \\
\hline
\end{tabular}

\subsubsection{Liner leakage}

Flow through a $1 \mathrm{~m}$ thick composite liner $\left(Q_{g}\right)$ is driven by the leachate head $(h)$ and calculated by a simple application of Darcy's law using the hydraulic conductivity $(K)$ of a combined (GM-CCL) liner system. $K$ is assumed to increase over time from its initial design value $\left(K_{c}\right)$ in response to a deterioration in the integrity of the GM (Figure 1).

The process of liner system deterioration and failure is complex and involves multiple interacting chemical and physical processes that, over time, adversely affect the material properties of the GM, such as its stress-crack resistance and crystallinity (Rowe, 2005). Liner temperature has been identified as a key controlling factor in liner longevity, with higher temperatures equating to a shorter service life (Rowe, 2005; Rowe et al., 2010). The default values used in this paper's model are based on the work of Rowe et al., 2010 and a liner temperature of $30^{\circ} \mathrm{C}$. This is considered to be a conservative estimate as although temperatures within the body of the landfill may be higher, the temperature of the liner will be regulated by the underlying geological material. The effect of more rapid liner deterioration as a result of increased liner temperature on the model's output was tested as part of a sensitivity analysis (see 3.4.1). 
Following an initial period of liner integrity loss (finishing at $T_{d}$ ), there is ongoing degradation of the GM up to the end of its service life $\left(T_{L}\right)$, at which point it is assumed that the hydraulic conductivity of the liner system is equal to that of the CCL $\left(K_{L}\right)$. The rate at which the hydraulic conductivity of a liner increases as it degrades is somewhat uncertain: an exponential form is indicated in Rowe (2005), whereas Drury et al. (2003) assume a linear decline. For simplicity, the model developed here has adopted a linear increase in liner hydraulic conductivity between its initial value $\left(K_{c}\right)$, the value at the start of degradation $\left(K_{d}\right)$ and the value at the end of the GM service life $\left(K_{L}\right)$. Default parameter values related to the performance of the liner are shown in Table 2.

Table 2. Default parameter values assigned to model the performance of the liner.

\begin{tabular}{|c|c|c|c|c|}
\hline Parameter & Notation & Unit & Value & Justification \\
\hline Flow through liner & $Q_{g}$ & $\mathrm{~mm} /$ year & - & \\
\hline Thickness of clay liner & $b$ & $\mathrm{~m}$ & 1 & $\begin{array}{l}\text { Regulatory requirement of the EU } \\
\text { Landfill Directive (European } \\
\text { Commission, 1999) }\end{array}$ \\
\hline Leachate head acting on liner & $h$ & $\mathrm{~m}$ & & \\
\hline $\begin{array}{l}\text { Initial hydraulic conductivity of } \\
\text { hybrid liner system }\end{array}$ & $K_{c}$ & $\mathrm{~m} / \mathrm{s}$ & $1 \times 10^{-11}$ & $\begin{array}{l}\text { Rowe (2005) cites data from } \\
\text { Bonaparte et al. }(2002) \text {. The mean } \\
\text { average monthly flow from three post- } \\
\text { closure sites with GM/CCL liners was } \\
50 \mathrm{~L} / \mathrm{Ha} / \mathrm{d} \text {. On the assumption that the } \\
\text { head was } 0.3 \mathrm{~m} \text { and the } \mathrm{CCL} \text { was } 0.6 \\
\mathrm{~m} \text { thick with a } \mathrm{K} \text { of } 1 \times 10^{-9} \mathrm{~m} / \mathrm{s} \text {, this } \\
\text { equates to a combined } \mathrm{K} \text { of } 3 \times 10^{-11} \\
\mathrm{~m} / \mathrm{s} \text { respectively. Rounding down, this } \\
\text { is approx. } 1 \times 10^{-11} \mathrm{~m} / \mathrm{s}\end{array}$ \\
\hline $\begin{array}{l}\text { Hydraulic conductivity of hybrid } \\
\text { liner system at start of degradation }\end{array}$ & $K_{d}$ & $\mathrm{~m} / \mathrm{s}$ & $5 \times 10^{-11}$ & $\begin{array}{l}\text { Assumed based on the premised that } \\
\text { before oxidation starts, a degree of } \\
\text { worsening in the GM performance will } \\
\text { have occurred due to physical } \\
\text { deterioration (Drury et al., 2003; } \\
\text { Rowe, 2005) }\end{array}$ \\
\hline $\begin{array}{l}\text { Hydraulic conductivity of CCL at } \\
\text { end of service life (i.e. when GM } \\
\text { component has degraded) }\end{array}$ & $K_{L}$ & $\mathrm{~m} / \mathrm{s}$ & $1 \times 10^{-9}$ & $\begin{array}{l}\text { Typical value for CCL (e.g. Giroud et } \\
\text { al., 1997; Rowe, 2005) }\end{array}$ \\
\hline $\begin{array}{l}\text { Time at which degradation of GM } \\
\text { liner starts }\end{array}$ & $T_{d}$ & years & 50 & $\begin{array}{l}\text { Table } 5 \text { in Rowe }(2005) \text { provides some } \\
\text { estimated oxidation depletion times } \\
\text { which are strongly temperature } \\
\text { dependent. For } 15^{\circ} \mathrm{C} \text {, 'inferred' and } \\
\text { 'simulated' times vary from } 100 \text { to } \\
280 \text { years. } 150 \text { years is taken as a } \\
\text { 'conservative midpoint' in this range. } \\
\text { At } 30^{\circ} \mathrm{C} \text {, both times are estimated to } \\
\text { be } 50 \text { years }\end{array}$ \\
\hline $\begin{array}{l}\text { Time at which GM liner has } \\
\text { degraded }\end{array}$ & $T_{L}$ & years & 200 & $\begin{array}{l}\text { Based on Table } 6 \text { Rowe (2005) for a } \\
\text { liner at } 30^{\circ} \mathrm{C}\end{array}$ \\
\hline
\end{tabular}




\subsubsection{Active control loss}

The effect of there being a period of active control loss, i.e. leachate is no longer removed to treatment, at a point in time $\left(T_{F}\right)$ is simulated by the discharge flow, $Q_{e}$, being set to zero for a period of time $(D)$. Uninterrupted active control is simulated by setting the duration of time during which leachate is not removed $(D)$ to 0 years. It is assumed that active control loss does not occur during the period of active aftercare operations $\left(T_{a}\right)$.

Depending on the balance between cap infiltration and liner leakage flow (which will increase as the leachate head builds up) it is possible that leachate levels in the landfill will increase. If the leachate level reaches the top of the site at a depth $h_{M}$, discharge to surface water is assumed to occur at a rate $Q_{s}$ calculated as the balance of $Q_{i}-Q_{g}$. When leachate control is restored following a period of active control loss, the model reverts to full control with leachate heads reduced to $h_{c}$. An instantaneous reduction of leachate heads in the basal drain and a cessation of discharge to surface water are both reasonable assumptions within the context of the long timescales being modelled. Default parameter values assigned to model the performance of active control systems are shown in Table 3.

Table 3. Default parameter values assigned to model the performance of active control systems.

\begin{tabular}{|c|c|c|c|c|}
\hline Parameter & Notation & Unit & Value & Justification \\
\hline $\begin{array}{l}\text { Managed leachate flow to } \\
\text { effluent }\end{array}$ & $Q_{e}$ & $\mathrm{~mm} /$ year & - & \\
\hline $\begin{array}{l}\text { Time at which leachate no } \\
\text { longer removed to } \\
\text { treatment }\end{array}$ & $T_{F}$ & years & $30-1,000$ & $\begin{array}{l}\text { This is varied to explore the effects of } \\
\text { this eventuality }\left(\geqslant T_{a}\right)\end{array}$ \\
\hline $\begin{array}{l}\text { Duration of period where } \\
\text { leachate not removed }\end{array}$ & $D$ & years & $0-10,000$ & $\begin{array}{l}\text { This is varied to explore the effects of } \\
\text { this eventuality }\end{array}$ \\
\hline $\begin{array}{l}\text { Controlled head under } \\
\text { normal operating } \\
\text { conditions }\end{array}$ & $h_{C}$ & $\mathrm{~m}$ & 0.3 & $\begin{array}{l}\text { Minimum realistically achievable } \\
\text { control head in drainage layers }\end{array}$ \\
\hline $\begin{array}{l}\text { Max head (i.e. to top of } \\
\text { landfill) }\end{array}$ & $h_{M}$ & $\mathrm{~m}$ & 20 & Based on a typical UK landfill \\
\hline $\begin{array}{l}\text { Drainable volumetric } \\
\text { water content }\end{array}$ & $\theta_{d}$ & - & 0.02 & Based on Beaven (2000) \\
\hline $\begin{array}{l}\text { Treatment efficiency for } \\
\text { species } i\end{array}$ & $\eta^{i}$ & - & $\begin{array}{l}\mathrm{As}=0.7 \\
\mathrm{Cd}=0.72 \\
\mathrm{Cr}=0.84 \\
\mathrm{Cu}=0.5 \\
\mathrm{~Pb}=0.92 \\
\mathrm{Hg}=0.85 \\
\mathrm{Ni}=0.2 \\
\mathrm{Zn}=0.7 \\
\mathrm{NH}_{3}-\mathrm{N}=0.98 \\
\text { Total-P }=0.22\end{array}$ & $\begin{array}{l}\text { Typical of average leachate treatment } \\
\text { technologies. As, } \mathrm{Cu}, \mathrm{Ni}, \& \mathrm{Zn} \text { based } \\
\text { on Robinson and } \mathrm{Knox}(2001) ; \mathrm{Cd}, \mathrm{Cr} \text {, } \\
\& \mathrm{~Pb} \text { based on Shafer et al. }(1998) ; \\
\mathrm{Hg}, \mathrm{NH}_{3}-\mathrm{N} \text {, and Total-P based on US } \\
\text { EPA }(2011)\end{array}$ \\
\hline
\end{tabular}




\subsubsection{Solute-transport behaviour}

The solute-transport behaviour of the landfill of surface area $A$ is simulated empirically as a black-box. The approach is based on results from Waste Acceptance Criteria (WAC) testing (Kosson et al., 2004) on a wide range of wastes and is described in detail elsewhere (Hjelmar et al., 2001, Hall et al., 2006a,b, Hjelmar et al., 2013). The initial concentration $\left(C_{0}\right)$ of each species $i$ is simulated as decaying exponentially with cumulative flow out of the landfill, where $\kappa^{i}$ is the rate constant (Drury et al., 2003), $L S$ is the liquid to solid ratio, $V_{C}$ is the cumulative flow volume out of the site and $m_{s}$ is the dry solid mass of waste.

$$
C^{i}=C_{0}^{i} \operatorname{EXP}\left[-k^{i} L S\right]=C_{0}^{i} \operatorname{EXP}\left[-k^{i} V_{C} / m_{S}\right]
$$

Therefore, the total flushable mass of each species under consideration is:

$$
m_{0}^{i}=\int_{0}^{\infty} C_{o}^{i} \operatorname{EXP}\left[-k^{i} V_{C} / m_{s}\right] d V_{C}=\frac{m_{s} C_{0}^{i}}{k^{i}}=\frac{\rho_{B} A h_{M} C_{0}^{i}}{k^{i}}
$$

There are a number of shortcomings of such a simplistic flushing model, not least the failure of exponential models to simulate the 'long' tail seen in some data. Heterogeneity of the waste mass (Fellner et al., 2009; Rosqvist et al., 2005, Woodman et al., 2014) is likely to be an important factor in determining the rate that contaminant can be removed. The model is essentially empirical with an absence of a firm physical or chemical basis. However, despite this concern, under certain conditions real landfill flushing processes can produce monotonically decaying concentrations, and even approximately exponential behaviour (Woodman et al., 2007). The exponential approach has been widely used in the literature (Straub and Lynch, 1982; Demetracopoulos et al., 1986; Reitzel et al., 1992), and for risk assessment purposes (Drury et al., 2003). The model has the advantage of considering how a variety of physical, chemical, and microbial processes affect each different species based on a single species-specific decay constant $\kappa^{i}$ (US EPA, 1999). For example, at an $L S$ of 10 the $C^{i} / C^{i}{ }_{0}$ ratio using $\kappa^{i}=30 \mathrm{~kg} / \mathrm{m}^{3}$ for arsenic is 0.74 , whereas for ammonia $\left(\kappa^{i}=590 \mathrm{~kg} / \mathrm{m}^{3}\right)$ it is 0.003 , which reflects the persistency of each species. For the purposes of this analysis, which is focussed on the potential impacts of site management, this model is adequate since it captures the primary pattern of flushing (i.e. a gradually diminishing rate of solute removal). Given the lack of a rigorous basis, the model should be implemented with caution, not least since, as with all empirical approaches, if the conditions vary outside of the data from which the parameters were estimated, the model's predictive power could become poor.

Eleven contaminant species are included in the analysis: eight heavy metals, As(III), Cd(II), $\mathrm{Cr}$ (III) or (VI), $\mathrm{Cu}(\mathrm{II}), \mathrm{Hg}(\mathrm{III}), \mathrm{Ni}(\mathrm{II}), \mathrm{Pb}(\mathrm{II})$, and $\mathrm{Zn}(\mathrm{II})$; ammoniacal nitrogen $\left(\mathrm{NH}_{3}-\mathrm{N}\right)$; and total phosphorous (Total-P). These species were selected based on their potential pollution risk to groundwater and surface waters, with heavy metals in particular known to be highly persistent and toxic in the natural environment. Other important landfill pollutants, such as dissolved organic carbon and chloride, were not included due to the lack of available life cycle impact assessment characterisation factors (see 2.4). Initial concentrations $\left(C_{0}^{i}\right)$ of each 
species $i$ were derived from the Pollution Inventory for England and Wales, which includes a database of species concentrations in raw leachates from landfill sites in Great Britain and Ireland (Robinson and Knox, 2001). For each species, the median value of concentration in sampled raw leachates from non-hazardous landfills was used. Based on the default values from the EASETECH LCA model, it is assumed that $90 \%$ of the total $\mathrm{Cr}$ is $\mathrm{Cr}(\mathrm{III})$ and $10 \%$ is $\mathrm{Cr}(\mathrm{VI})$.

Leaching rates, expressed by the decay constant $\kappa^{i}$, for different species were based on the values used by Hall et al. (2006b), which are the same as the default values from the LandSim 2.5 software. LandSim is a groundwater risk assessment tool for landfill design developed by Golder Associates on behalf of the Environment Agency (Drury et al., 2003). Default parameter values assigned to model solute-transport behaviour are shown in Table 4.

Table 4. Default parameter values assigned to model solute-transport behaviour.

\begin{tabular}{|c|c|c|c|c|}
\hline Parameter & Notation & Unit & Value & Justification \\
\hline $\begin{array}{l}\text { Total volumetric } \\
\text { water content }\end{array}$ & $\theta_{T}$ & - & 0.4 & Based on Beaven (2000) \\
\hline $\begin{array}{l}\text { Decay constant for } \\
\text { species } i \text { ('kappa } \\
\text { value') }\end{array}$ & $\kappa^{i}$ & $\mathrm{~kg} / \mathrm{m}^{3}$ & $\begin{array}{l}\mathrm{As}=30 \\
\mathrm{Cd}=350 \\
\mathrm{Cr}=180 \\
\mathrm{Cu}=570 \\
\mathrm{~Pb}=270 \\
\mathrm{Hg}=50 \\
\mathrm{Ni}=290 \\
\mathrm{Zn}=280 \\
\mathrm{NH}_{3}-\mathrm{N}=590 \\
\text { Total-P }=590\end{array}$ & $\begin{array}{l}\text { Values representative of a typical MSW } \\
\text { stream and taken from Golder Associates } \\
(2008) \text {. Note that due to a lack of specific } \\
\text { data, the value for } \mathrm{NH}_{3}-\mathrm{N} \text { was used as a proxy } \\
\text { for Total-P }\end{array}$ \\
\hline Bulk (dry) density & $\rho_{B}$ & $\mathrm{~kg} / \mathrm{m}^{3}$ & 800 & Typical of UK MSW (Beaven, 2000) \\
\hline $\begin{array}{l}\text { Initial concentration } \\
\text { of species } i\end{array}$ & $C_{0}{ }^{i}$ & $\mathrm{mg} / \mathrm{l}$ & $\begin{array}{l}\mathrm{As}=0.01 \\
\mathrm{Cd}=0.006 \\
\mathrm{Cr}=0.05 \\
\mathrm{Cu}=0.016 \\
\mathrm{~Pb}=0.05 \\
\mathrm{Hg}=0.0005 \\
\mathrm{Ni}=0.08 \\
\mathrm{Zn}=0.152 \\
\mathrm{NH}_{3}-\mathrm{N}=501 \\
\text { Total-P }=3.2\end{array}$ & $\begin{array}{l}\text { Median values of leachate sample data from } \\
\text { full scale landfill sites in Great Britain, as } \\
\text { presented by Robinson and Knox (2001). }\end{array}$ \\
\hline Area of landfill & $A$ & $\mathrm{~m}^{2}$ & 10,000 & Nominal value for a cell \\
\hline
\end{tabular}

\subsubsection{Effect of leachate treatment}

As evaluation of leachate treatment technologies is not a focus of this paper (see Robinson and Knox, 2001), treatment efficiencies ( $\eta^{i}$ ) for each species $i$ were selected to be representative of typical leachate treatment in the UK (see Table 3): on-site biological purification, including a combined nitrification-denitrification system, prior to discharge into 
the sewer and further treatment at a wastewater treatment plant (EA, 2007). Wastewater treatment effluents were assumed to be discharged to surface water.

\subsection{Aftercare scenarios}

To examine the effects of different types of landfill aftercare management, four scenarios were compared in this study. Whilst hypothetical, these scenarios were designed to reflect real-world landfill aftercare strategies. The four scenarios are as follows:

S1 Typical aftercare - low permeability cap as typically adopted by operators in much of the developed world.

S2 Accelerated aftercare (high permeability cap) - high permeability cap that allows effective rainfall of $250 \mathrm{~mm} /$ year to enter the site.

S3 Accelerated aftercare (30 year moisture injection) - high permeability cap and injection of an additional $750 \mathrm{~mm} /$ year of moisture into the site (i.e. $1000 \mathrm{~mm} /$ year total) during a 30 year active aftercare operations period. Following this period, infiltration is equal to effective rainfall (i.e. $250 \mathrm{~mm} /$ year).

S4 Accelerated aftercare (60 year moisture injection) - high permeability cap and injection of an additional $750 \mathrm{~mm} /$ year of moisture into the site (i.e. $1000 \mathrm{~mm} /$ year total) during a 60 year active aftercare operations period. Following this period, infiltration is equal to effective rainfall (i.e. $250 \mathrm{~mm} /$ year).

For each scenario, several parameters were varied from the default values, as shown in Table 5. Based on the approach planned by the Dutch Sustainable Landfill Foundation for field scale accelerated completion trials in the Netherlands (see Kattenberg et al., 2013), the additional moisture that is injected into the landfill in S3 and S4 was assumed to be either fresh water or treated wastewater effluent containing minimal (assumed zero) contaminant concentrations.

Table 5. Model input parameter values assigned for each aftercare scenario.

\begin{tabular}{lllllll}
\hline Parameter & Notation & Unit & Value & & \\
& & & $\mathrm{S} 1$ & $\mathrm{~S} 2$ & $\mathrm{~S} 3$ & $\mathrm{~S} 4$ \\
\hline Design flow through cap & $Q_{i-d}$ & mm/year & 50 & 250 & 1,000 & 1,000 \\
Flow through cap at end of 'active aftercare period' & $Q_{i-a}$ & mm/year & 60 & 250 & 1,000 & 1,000 \\
& & & & & & \\
& & & & & & \\
& & & & \\
& & & & \\
Flow $/$ year & 250 & 250 & 250 & 250 \\
Time at end of 'active aftercare operations period' & $T_{a}$ & years & 30 & 30 & 30 & 60 \\
Time at end of cap 'service life' & $T_{s}$ & years & 1,000 & 30 & 30 & 60 \\
\hline
\end{tabular}




\subsection{Life cycle impact assessment}

In the life cycle impact assessment (LCIA) phase, emissions to the environment, generated here by the mechanistic model, are translated into potential impacts on human health and the environment. In this study, five impact categories were selected for inclusion based on their relevance to aqueous emissions: carcinogenic human toxicity $(\mathrm{HTc})$, non-carcinogenic human toxicity (HTnc), ecotoxicity (ET), freshwater eutrophication (EUf), and marine eutrophication (EUm).

For each impact category, characterisation factors were calculated by applying the recommended LCIA methods outlined in JRC-IES (2011). Characterisation factors express the individual contributions of each environmental emission to the impact categories, relative to a reference flow (defined here as a quantified mass of leachate contaminant). For EUf and EUm, characterisation factors were calculated using ReCiPe, a LCIA method developed in the Netherlands (Goedkoop et al., 2013). This method is well acknowledged and, hence, the degree of confidence in the eutrophication potential impacts can be considered high.

Characterisation factors for toxicity-related impact categories, namely HTc, HTnc, and ET, were calculated using USEtox, a LCIA model developed for characterising emissions of organic and inorganic substances into potential human- and eco-toxicological impacts (Rosenbaum et al., 2008). USEtox is currently still under development and the degree of certainty in the toxicity-related impact categories is considered low (Hauschild et al., 2013). Furthermore, USEtox does not provide specific characterisation factors for emissions to groundwater. Here, these potential impacts were approximated using the characterisation factors for emissions to freshwater, an approach consistent with that of Schwab et al. (2014). Based on Doka (2009), the fate of all emissions through the liner was assumed to be the groundwater receptor. The influence of this assumption on the model's outputs was tested as part of a sensitivity analysis (see 3.4.2).

The characterised results from each impact category were normalised through conversion to person equivalents (PE), which represent the impact of one person in a given area during a given reference year (Stranddorf et al., 2005). The purpose of normalisation is to place the characterised impact results into a broader context, enhance comprehensibility, and enable comparisons between the relative contributions of different impact categories (ISO, 2006a; Kim et al., 2013). In this study, the normalisation reference values provided by Laurent et al. (2013) were applied (see Table 6). These reference values reflect global per capita contributions to impact categories in the reference year 2010, expressed as PE. 
Table 6. Normalised reference values applied for each impact category to convert characterised results to person equivalents $(\mathrm{PE})$.

\begin{tabular}{|c|c|c|c|c|}
\hline Impact category & Acronym & Indicator & Units & $\begin{array}{l}\text { Normalisation } \\
\text { reference value }\end{array}$ \\
\hline $\begin{array}{l}\text { Carcinogenic human } \\
\text { toxicity }\end{array}$ & HTc & $\begin{array}{l}\text { Comparative Toxic Unit for } \\
\text { human health }\left(\mathrm{CTU}_{\mathrm{h}}\right)\end{array}$ & Cases/person/year & $5.42 \mathrm{E}-05$ \\
\hline $\begin{array}{l}\text { Non-carcinogenic } \\
\text { human toxicity }\end{array}$ & HTnc & $\begin{array}{l}\text { Comparative Toxic Unit for } \\
\text { human health }\left(\mathrm{CTU}_{\mathrm{h}}\right)\end{array}$ & Cases/person/year & 0.0011 \\
\hline $\begin{array}{l}\text { Freshwater } \\
\text { ecotoxicity }\end{array}$ & ET & $\begin{array}{l}\text { Comparative Toxic Unit for } \\
\text { ecosystems }\left(\mathrm{CTU}_{\mathrm{e}}\right)\end{array}$ & $\begin{array}{l}\mathrm{PAF} / \mathrm{m}^{3} / \\
\text { day/person/year }\end{array}$ & 665 \\
\hline $\begin{array}{l}\text { Freshwater } \\
\text { eutrophication }\end{array}$ & EUf & $\begin{array}{l}\text { Fraction of nutrients } \\
\text { reaching freshwater end } \\
\text { compartment }\end{array}$ & kg P-eq/person/year & $0.62^{\mathrm{a}}$ \\
\hline $\begin{array}{l}\text { Marine } \\
\text { eutrophication }\end{array}$ & EUm & $\begin{array}{l}\text { Fraction of nutrients } \\
\text { reaching marine end } \\
\text { compartment }\end{array}$ & kg N-eq/person/year & $9.38^{\mathrm{a}}$ \\
\hline
\end{tabular}

Source: adapted from Laurent et al. (2013).

PAF, potentially affected fraction of species.

${ }^{a}$ Note that the normalisation values for marine and freshwater eutrophication were developed by Laurent et al. (2013) for the reference year 2000 and were extrapolated by the authors to reflect the global situation in 2010.

\section{Results}

\subsection{Contaminant mass}

For each aftercare scenario, the total mass of contaminants that is discharged from the landfill via the $Q_{e}$ (managed flow to effluent), $Q_{g}$ (flow through liner), and $Q_{s}$ (overflow to surface water) pathways over the 10,000 year time horizon is presented in Figure 3. The figure summarises the results for the continuum of control loss possibilities. Further details are provided below, particularly for the two 'end member' situations: the 'best case', where control is never lost ( $D=0$ years); and the 'worst case', where control fails at the earliest possible point and is never reinstated $\left(D=10,000\right.$ years and $\left.T_{F}=T_{a}\right)$. 


\section{S1 Typical aftercare}
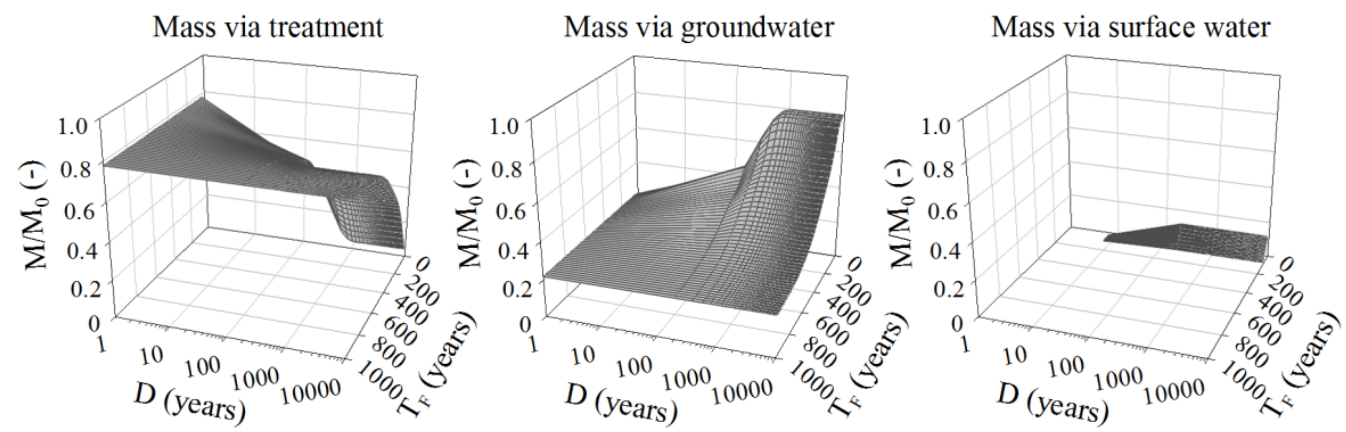

S2 Accelerated aftercare (high permeability cap)
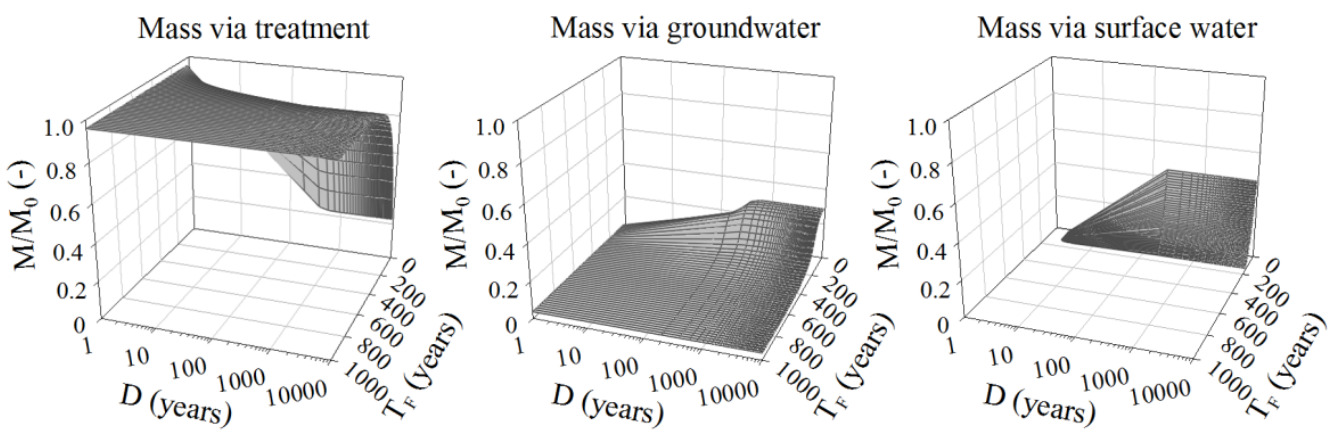

S3 Accelerated aftercare (30 year moisture addition)
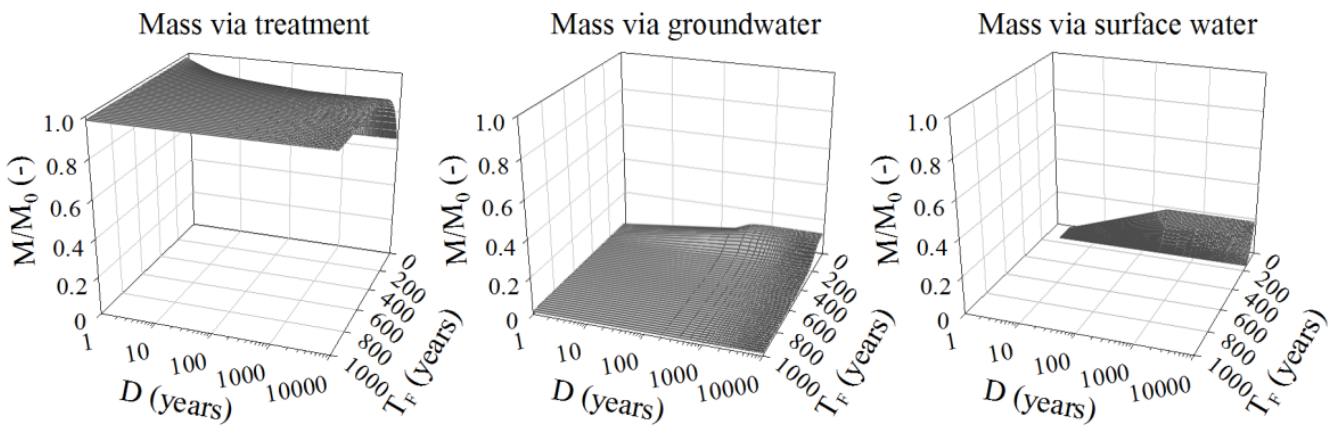

S4 Accelerated aftercare (60 year moisture addition)
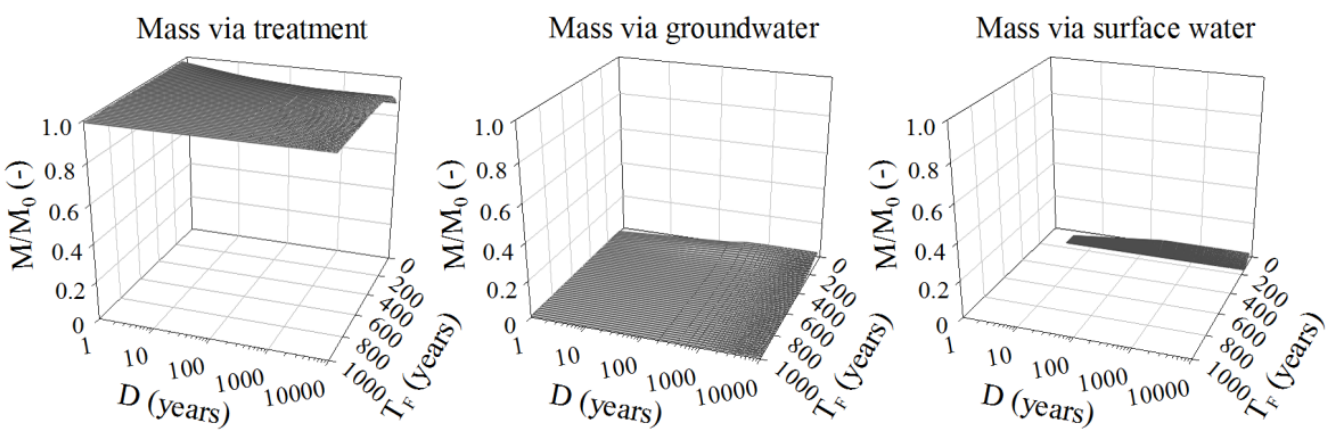

Figure 3. The proportion of leachate contaminants that, during the 10,000 year inventory time horizon, follows the treatment, groundwater, or surface water pathways for each scenario (expressed as $M / M_{0}$, where $M_{0}$ is the initial mass of contaminant species and $\mathrm{M}$ is the mass at a given time) as a function of $T_{F}$ (time at which active control is lost) and $D$ (duration of control loss). 


\subsection{1 'Best case' - no active control loss}

In the situation of no active control loss, no leachate reaches the surface water via $Q_{s}$ in any scenario. In the typical aftercare scenario ( $\mathrm{S} 1$; see 2.3 ), approximately $80 \%$ of leachate contaminants are collected for treatment, with $20 \%$ reaching groundwater via $Q_{g}$. By comparison, in the accelerated aftercare scenarios (S2-S4), most of the contaminants are collected for treatment ( $>95 \%$ ), whilst less than 5\% reaches groundwater. For S4, the proportion that reaches groundwater is less than $1 \%$.

\subsection{2 'Worst case' - indefinite loss of control at end of active aftercare period}

For S1, if active control is lost indefinitely at $T_{F}=T_{a}$, only $7 \%$ of contaminants are collected for treatment, whilst $13 \%$ overflow to surface water and $80 \%$ flow through the liner to groundwater. For S2 and S3, the worst case active control loss situation results in a substantial proportion of contaminants reaching surface water via $Q_{s}(46 \%$ and $20 \%$, respectively) and comparatively less reaching groundwater (30\% and $13 \%$, respectively). For S4, even if control is lost indefinitely at $T_{F}=T_{a}$, only around $6 \%$ and $5 \%$ of contaminants reach the groundwater and surface water receptors (via $Q_{s}$ ), respectively.

\subsection{Potential impacts by pathway}

Based on the mass of contaminant species discharged to different receptors via each pathway (see Figure 3), a compatible set of potential impacts were calculated using LCA, which are described below. Figure 4 presents, for each aftercare scenario, the normalised potential impacts of leachate emissions to the groundwater and surface water receptors via the $Q_{e}, Q_{g}$, and $Q_{s}$ pathways, as a function of $T_{F}$ and $D$. The total normalised potential impacts (i.e. the summation of the potential impacts of all emissions) for each scenario are also presented in the rightmost graphs of Figure 4 and summarised in Table 7. 


\section{S1 Typical aftercare}
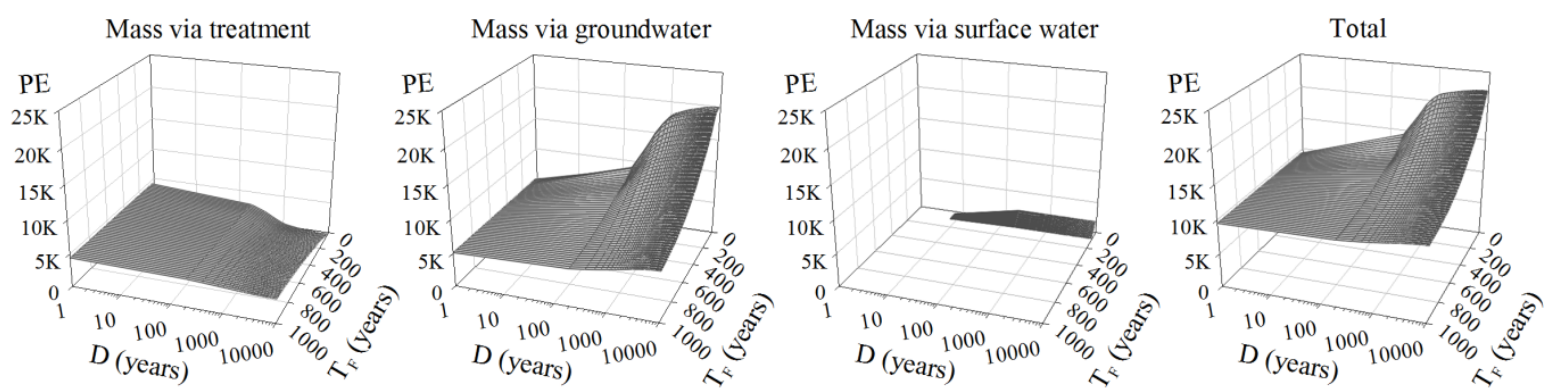

S2 Accelerated aftercare (high permeability cap)
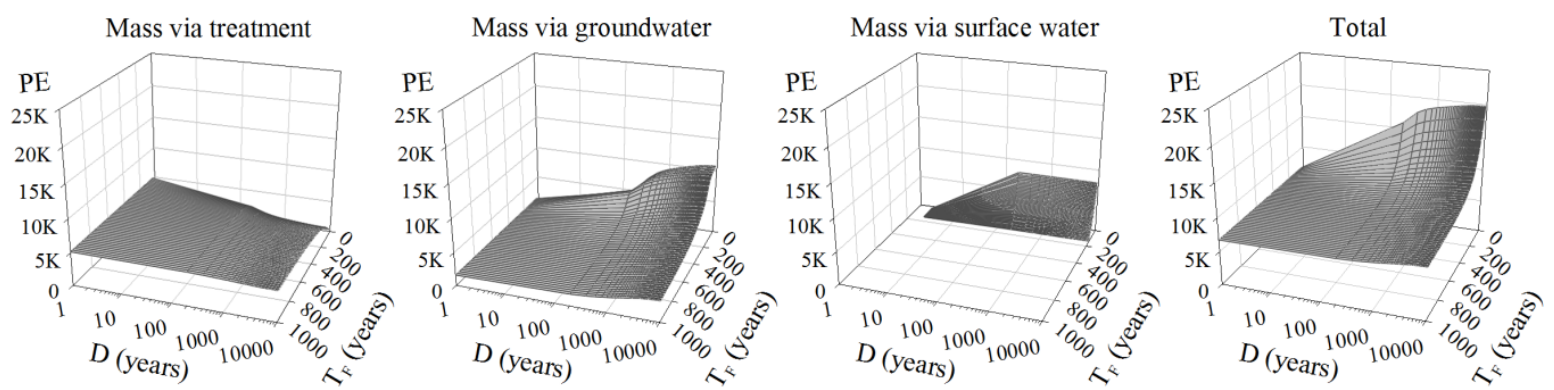

S3 Accelerated aftercare (30 year moisture addition)
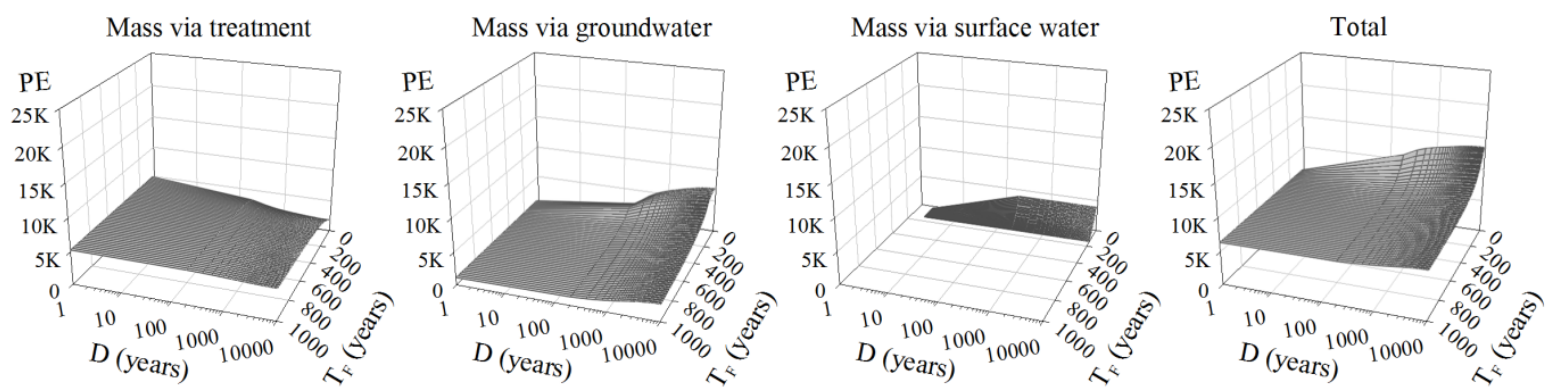

S4 Accelerated aftercare (60 year moisture addition)
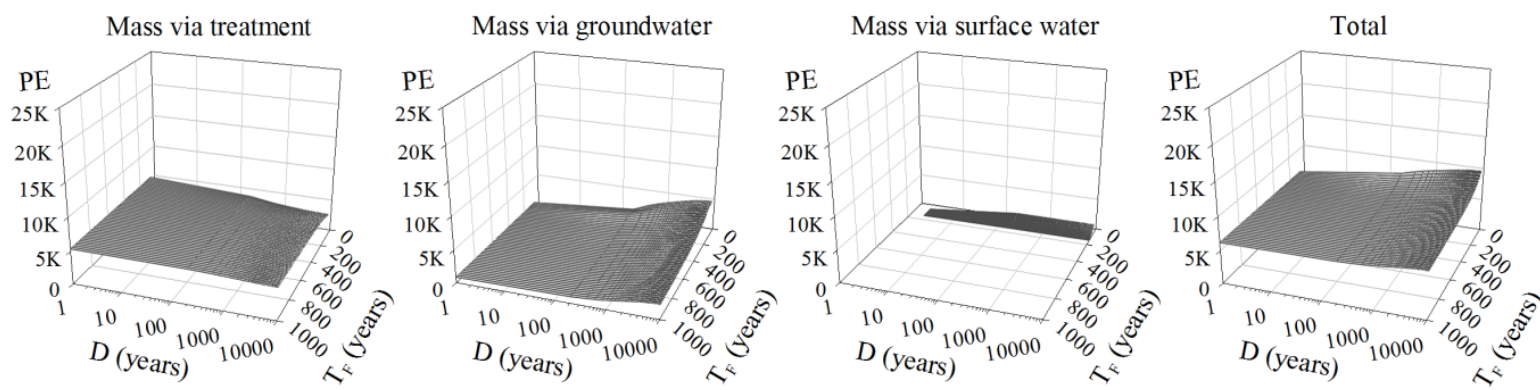

Figure 4. Comparison of total normalised potential impacts (expressed as person equivalents [PE]) for each scenario by pathway (treatment, groundwater, or surface water) as a function of $T_{F}$ (time at which active control is lost) and $D$ (duration of control loss). Overall total normalised potential impacts for each scenario (i.e. the summation of the total normalised potential impacts by pathway) are displayed on the rightmost graph for each scenario. 
Table 7. Comparison between the total normalised potential impacts for each scenario in the 'best case' (i.e. $D$ $=0$ years) and 'worst case' (i.e. $D=10,000$ years and $T_{F}=T_{a}$ ) active control situations. Also shown are the potential impacts from the ecotoxicity (ET), and marine eutrophication (EUm) impact categories.

$\begin{array}{lll}\text { Active control situation } & & \\ \text { 'Best case' 'Best case' 'Worst case' 'Worst case' } \\ (\mathrm{PE}) & \left(\mathrm{PE} / \mathrm{t}^{\mathrm{a}}\right) & (\mathrm{PE})\end{array}$

Increase on

$(\mathrm{PE})$

$\left(\mathrm{PE} / \mathrm{t}^{\mathrm{a}}\right)$

$(\mathrm{PE} / \mathrm{t})$ 'best case' $(\%)^{b}$

\section{S1 Typical aftercare}

$\begin{array}{llllll}\text { Total } & 9,530 & 0.060 & 22,560 & 0.14 & 136 \\ \text { ET } & 4,390 & 0.027 & 8,080 & 0.051 & 84 \\ \text { EUm } & 2,640 & 0.017 & 10,600 & 0.066 & 302\end{array}$

S2 Accelerated aftercare (high permeability cap)

$\begin{array}{llllll}\text { Total } & 6,760 & 0.042 & 20,050 & 0.13 & 197 \\ \text { ET } & 3,750 & 0.023 & 7,660 & 0.048 & 104 \\ \text { EUm } & 630 & 0.004 & 8,590 & 0.054 & 1263\end{array}$

S3 Accelerated aftercare (30 year moisture injection)

$\begin{array}{llllll}\text { Total } & 6,400 & 0.040 & 13,880 & 0.087 & 117 \\ \text { ET } & 3,640 & 0.023 & 6,440 & 0.040 & 77 \\ \text { EUm } & 400 & 0.003 & 3,870 & 0.024 & 868\end{array}$

S4 Accelerated aftercare (60 year moisture injection)

$\begin{array}{lllllll}\text { Total } & 6,210 & 0.039 & 10,220 & 0.064 & 65 \\ \text { ET } & 3,560 & 0.022 & 5,410 & 0.034 & 52 & 377 \\ \text { EUm } & 300 & 0.002 & 1,430 & 0.009 & 377\end{array}$

${ }^{\text {a }} \mathrm{PE} / \mathrm{t}=\mathrm{PE} /$ tonne wet weight

b Calculated as ('worst case' PE - 'best case' PE) / 'best case' PE

$\mathrm{PE}$, person equivalents; ET, ecotoxicity; EUm, marine eutrophication.

\subsection{1 'Best case' - no active control loss}

In the 'best-case' situation where active control is maintained indefinitely, the total potential impacts for S1 are approximately 30-35\% greater than those for S2-S4. For S1, the dominant source of potential impacts was from emissions to groundwater via $Q_{g}(54 \%$ of total PE), whilst the potential impacts of emissions to surface water via $Q_{e}$ (i.e. managed flow to effluent) were also substantial (46\% of total PE). For the accelerated aftercare scenarios (S2S4), the dominant source of potential impacts came from the discharged effluent flow via $Q_{e}$ (76-86\% of total PE), with the potential impacts of emissions to groundwater via $Q_{g}$ found to be considerably lower compared with $\mathrm{S} 1$.

\subsection{2 'Worst case' - indefinite loss of control at end of active aftercare period}

In the 'worst case' situation where active control is lost indefinitely at $T_{F}=T_{a}$, S1 resulted in the greatest potential impacts $(22,560 \mathrm{PE})$. The total potential impacts for S2 in the 'worst case' are around $10 \%$ lower than those of S1, whilst the total potential impacts for S3 and S4 are $40 \%$ and $55 \%$ lower, respectively. For S1, the dominant source of potential impacts in 
the 'worst case' was from emissions to groundwater (89\% of total PE). For S2 and S3, contributions were more evenly split between overflow to surface water via $Q_{s}(53 \%$ and $55 \%$ of total $\mathrm{PE}$, respectively) and emissions to groundwater ( $41 \%$ and $31 \%$ of total $\mathrm{PE}$, respectively). For S4, the dominant source of potential impacts in the 'worst case' was from emissions to groundwater ( $52 \%$ of total $\mathrm{PE}$ ), whilst potential impacts from overflow to surface water via $Q_{s}(15 \%$ of total $\mathrm{PE})$ were less than half those of the managed flow to effluent ( $33 \%$ of total PE).

In the case of S1, it takes approximately 25 years of no active control (within the 10,000 year time horizon) before total potential impacts increase by 5\% compared to the 'best case' for the scenario. For S2-S4, the duration of active control loss that is required before total potential impacts increase by 5\% compared to the 'best case' for S1 is much longer, at around 40 and 100 years for S2 and S3, respectively, and around 8,000 years for S4.

\subsubsection{Time after which indefinite loss of control becomes insignificant}

For all scenarios, the time after which active control can be lost $\left(T_{F}\right)$ indefinitely and not result in a 5\% increase in total potential impacts (compared to the 'best case' for each respective scenario) is between 2,900 years for S1 and 3,300 years for S4. However, where total potential impacts for S2-S4 are compared with the 'best case' for S1, the active control period required before total potential impacts increase by $5 \%$ is much shorter, ranging from 280 years for S2 to 70 years for S4.

\subsection{Potential impacts by impact category}

The normalised potential impacts for each scenario are presented in Figure 5 by impact category as a function of $T_{F}$ and $D$. Generally, the greatest potential impacts for all scenarios and for all active control situations were from ET and EUm (see Table 7), whilst potential impacts from HTc, HTnc, and EUf were found to be relatively minor.

\subsection{1 'Best case' - no active control loss}

In the 'best case' active control situation, ET is the dominant source of potential impacts for all scenarios, contributing between $46-57 \%$ of total PE. ET impacts for S1 are between $17-$ $23 \%$ greater than those for S2-S4. The dominant species that contribute to ET impacts are, in order or importance, $\mathrm{Zn}(\mathrm{II}), \mathrm{Ni}(\mathrm{II}), \mathrm{Cr}(\mathrm{VI})$, and $\mathrm{As}(\mathrm{III})$.

Potential impacts from EUm, caused by emissions of $\mathrm{NH}_{3}-\mathrm{N}$, vary considerably between scenarios. For S2-S4, the contribution to the total potential impact from EUm is less than $10 \%$, whilst for $\mathrm{S} 1$ it is around $30 \%$.

\subsection{2 'Worst case' - indefinite loss of control at end of active aftercare period}

In the 'worst case' active control situation, ET remains the largest source of potential impacts for S3 and S4, whereas for S1 and S2 EUm impacts dominate. $\mathrm{Zn}(\mathrm{II})$ is the dominant source 
of ET impacts, comprising between 51-61\% of ET impacts for each scenario. For S1-S3, the ET impacts of $\mathrm{Zn}$ (II) more than doubled in the 'worst case' compared with the 'best case', whilst they increased by $67 \%$ for S4.
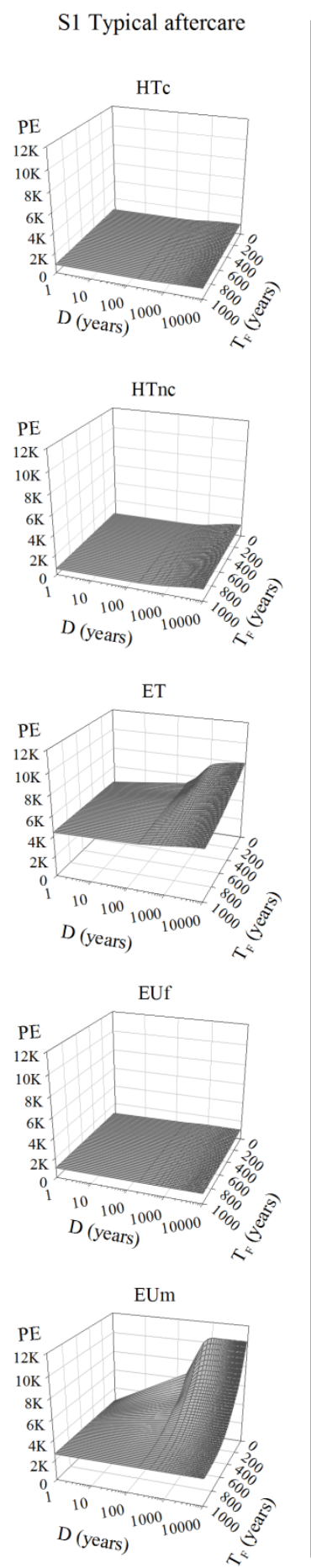

S2 Accelerated aftercare (high permeability cap)
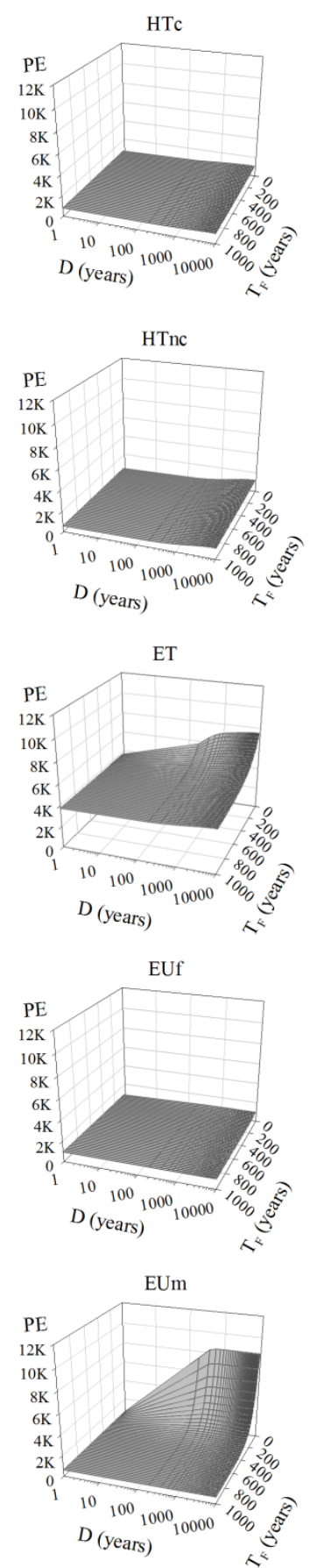

S3 Accelerated aftercare (30 year moisture addition)
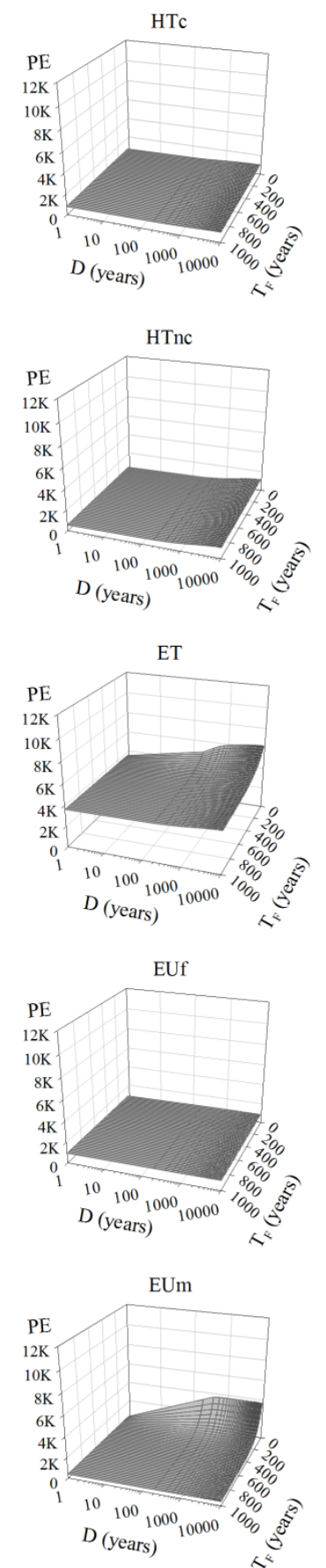

S4 Accelerated aftercare (60 year moisture addition)
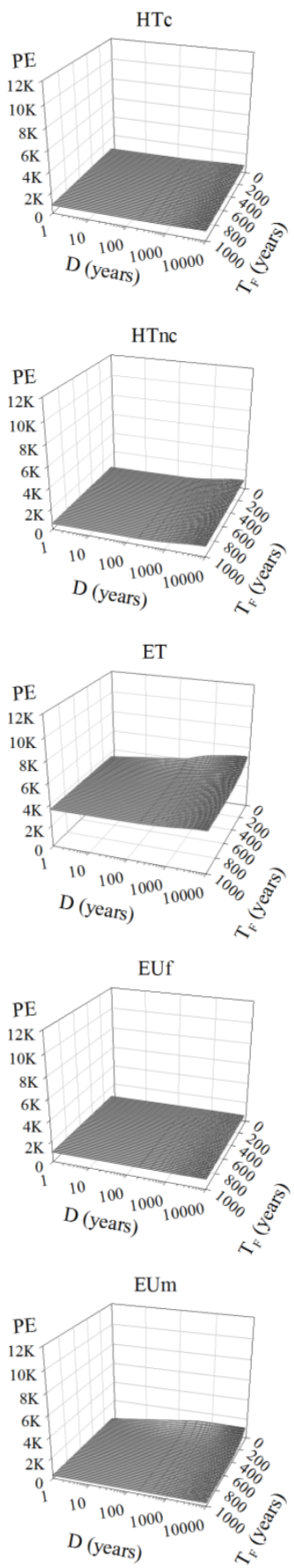

Figure 5. Comparison of normalised impact potentials (expressed as person equivalents [PE]) for each scenario by impact category as a function of $T_{F}$ (time at which active control is lost) and $D$ (duration of control loss). HTc, human toxicity, carcinogenic; HTnc, human toxicity, non-carcinogenic; ET, ecotoxicity; EUf, freshwater eutrophication; EUm, marine eutrophication. 


\subsection{Sensitivity analysis}

Two sensitivity analyses were performed: a) a parameter perturbation analysis to identify those input parameters with the greatest influence on the results, and b) a scenario analysis into the effect of partitioning of emissions through the liner between the groundwater and soil receptors.

\subsubsection{Parameter perturbation analysis}

For the perturbation analysis, the default value of each parameter was varied by $\pm 10 \%$ and a sensitivity ratio (SR) was calculated. The SR is the ratio between the percentage change in the model's result and the percentage change in the parameter value (Clavreul et al., 2012), i.e. a parameter SR greater than 1 (as absolute value) implies that a variation of the parameter value induces a greater relative variation in the model output. Parameter SRs, presented in Figure 6, were calculated for the 'best' and 'worst' case active control situations for the default model setup (i.e. S1). Note that only parameter SRs $>0.2$ are presented. Generally, the parameters that most greatly influence the results are those that control the concentrations of $\mathrm{NH}_{3}-\mathrm{N}$ and $\mathrm{Zn}(\mathrm{II})$ in the leachate over time and, in 'best case', their treatment efficiencies.

'Best case' active control situation

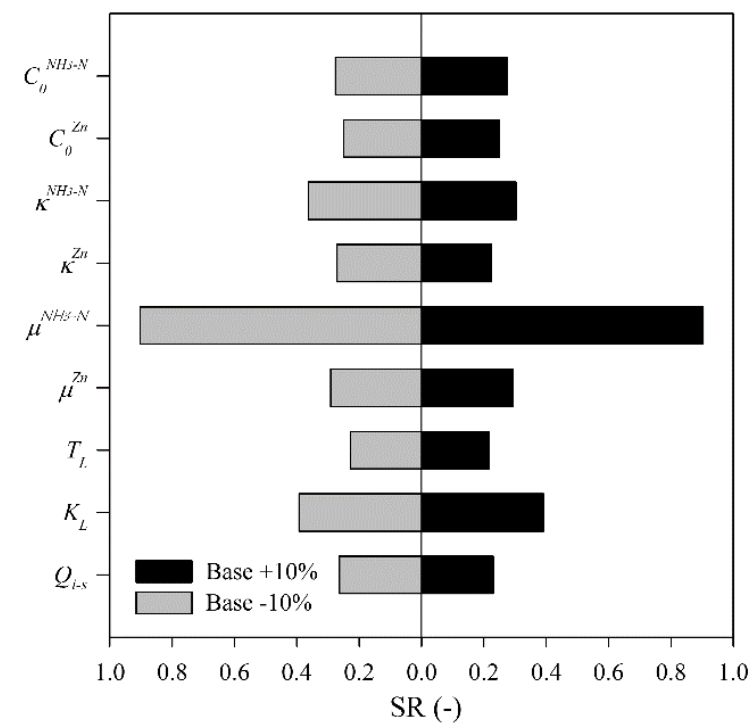

'Worst case' active control situation

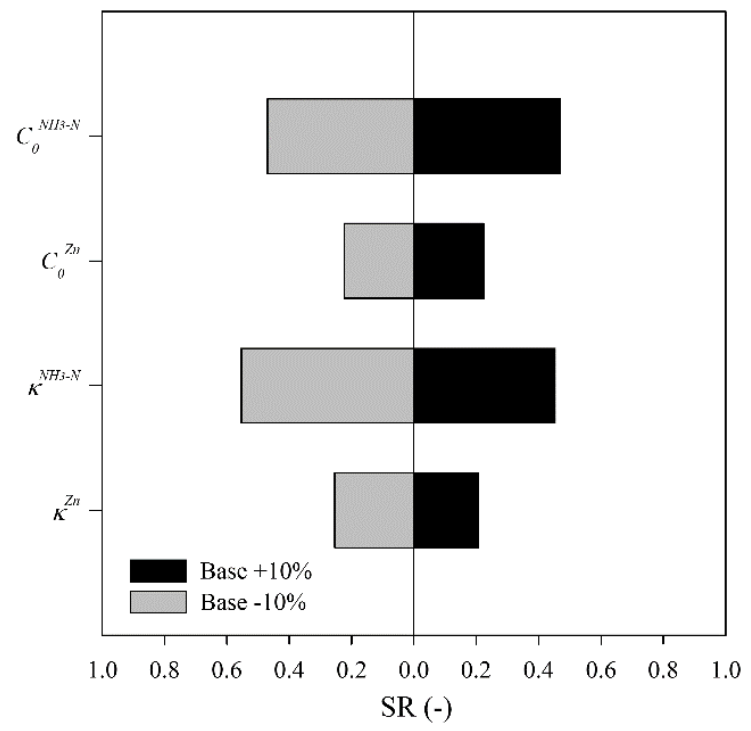

Figure 6. Parameter sensitivity ratios (SR) calculated for typical aftercare scenario S1 for a) uninterrupted active control ('best case') and b) active control ending at $T_{a}$ ('worst case'). Note that only SR values greater than 0.2 (as absolute value) are presented.

\subsubsection{Partitioning of emissions through the liner}

An analysis was performed to investigate the sensitivity of the model's output to a variation in the partitioning of emissions through the liner $\left(Q_{g}\right)$ between the groundwater and soil receptors. For the analysis, the initial assumption that $100 \%$ of emissions via $Q_{g}$ would reach 
the groundwater receptor was changed to a 50:50 partitioning between the groundwater and soil receptors, which reflects the approach of Hauschild et al. (2008). The influence of this change on the potential impacts in the 'best' and 'worst case' active control situations for each scenario was tested..

Figure 7 presents the results of the scenario analysis. In the 'best case', the ranking of scenarios in respect of their total potential impacts was not affected by partitioning between soil and groundwater receptors. Conversely, in the 'worst case', the ranking of scenarios was affected by the change in emissions partitioning, with S2, rather than S1, found to have the greatest total potential impacts in the analysis. Whilst total potential impacts for S1 were found to be greatly reduced in the analysis $(-5,970 \mathrm{PE} ;-26 \%$ of total PE), the results for S2, also lower in the analysis $(-2,710 \mathrm{PE} ;-13 \%$ of total $\mathrm{PE})$, were not as affected by the change.
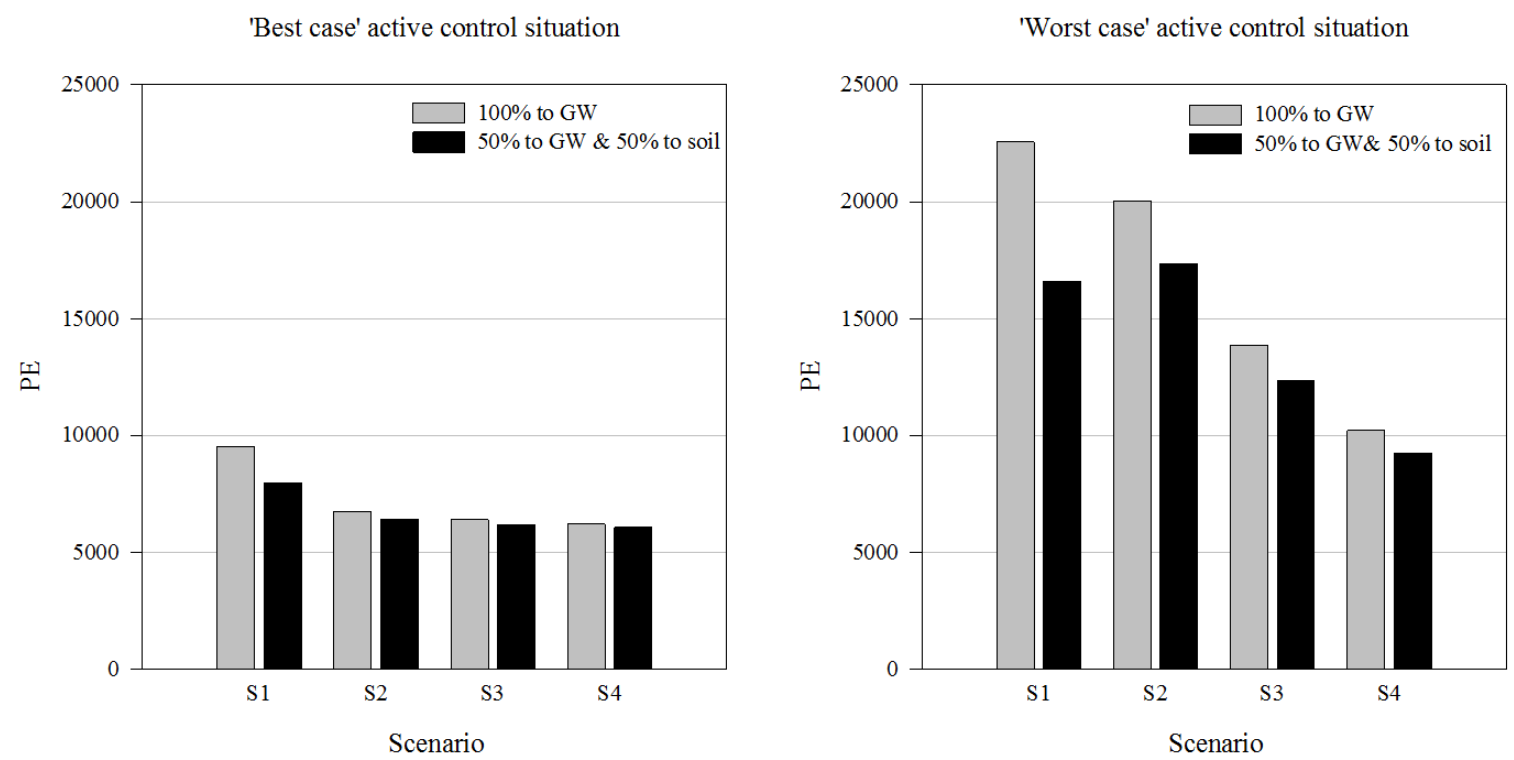

Figure 7. Comparison between the total normalised potential impacts (expressed in person equivalents [PE]) for different partitioning to soil and groundwater (GW) for a) uninterrupted active control ('best case') and b) active control ending at $T_{a}$ ('worst case'). The results for the case where $100 \%$ of emissions via $Q_{g}$ reach the groundwater receptor are presented as grey bars, whilst the black bars present the results for the case where 50:50 partitioning of emissions via $Q_{g}$ between the groundwater and soil receptors.

\section{Discussion}

\subsection{Comparison of aftercare scenarios}

The typical aftercare scenario (S1) was found to result in the greatest total potential impacts compared with the accelerated aftercare scenarios (S2-S4) in both the 'best case' (i.e. $D=0$ years) and 'worst case' (i.e. $T_{F}=T_{a} ; D=10,000$ years) active control situations. In the 'best case', the total potential impacts for S1 were found to be approximately double those of S2S4. This is mainly due to the relatively high proportion of contaminants that flow through the 
liner to groundwater in S1 ( 20\%). The underlying containment concept of S1 means that only a small proportion of contaminants are flushed from the landfill via $Q_{e}$ (managed flow to effluent) before the liner has deteriorated significantly. A large proportion of contaminants therefore remain in the leachate as its leakage through the liner $\left(Q_{g}\right)$ to groundwater accelerates. By comparison, the underlying concepts of S2-S4 result in a greater proportion of contaminants being flushed out of the landfill before the liner begins deteriorating and a much lower proportion reach groundwater. This finding accords with that of Manfredi and Christensen (2009), who found that emissions to groundwater were significantly reduced where flushing bioreactor technology was used rather than a conventional containment approach.

If active control is lost early into the post-active aftercare operations period, the higher infiltration rates of S2-S4 cause a rapid rise in the depth of the leachate head and consequent leachate discharge to surface water $\left(Q_{s}\right)$. The LCIA results show that this 'overtopping' incurs considerable potential impacts, particularly of EUm due to emissions of $\mathrm{NH}_{3}$, a result also observed by Manfredi and Christensen (2009). Despite this, for S2-S4 the duration of active control loss at the end of active aftercare operations that is required before potential impacts increase above those for the 'best case' for $\mathrm{S} 1$ is considerable - up to 8,000 years in the case of S4. This finding emphasises the magnitude of the potential impacts of S1, even where active control is maintained indefinitely.

The low-permeability capping system installed in S1 ensures that overtopping of leachate rarely ever occurs, even if active control is lost. Despite this, even in the 'worst case' active control situation, the potential impacts for S1, which increased 2.4 times compared with the $\mathrm{S} 1$ in 'best case', were found to be greater than those for S2-S4. This is because for S1 over the 10,000 year time horizon the majority of contaminants end up flowing through the liner to groundwater, resulting in considerable EUm and ET impacts. This finding reflects that of Güereca et al. (2006), who also found that leakage of landfill leachate to groundwater caused substantial potential eutrophication impacts. The potential impacts of emissions to groundwater are, however, are highly uncertainty due to the lack of groundwater-specific LCIA characterisation factors (see 2.4). Furthermore, the results of the scenario analysis (see 3.4.2) show that, if the partitioning of emissions via $Q_{g}$ is split evenly between the groundwater and soil receptors (rather than 100\% reaching groundwater), the potential impacts of emissions via $Q_{g}$ decrease substantially and the total potential impacts for $\mathrm{S} 1$ in the 'worst case' are greatly reduced. To minimise this uncertainty and enhance the reliability of the results, more sophisticated contaminant fate and transport modelling that considers the partitioning and speciation of emissions between and in environmental media is required (Hellweg et al., 2005; Schwab et al., 2014).

The total potential impacts for S3 and S4 in the 'worst case' were, respectively, 2.2 and 1.6 times greater than those in the 'best case' for each scenario and were considerably lower than the 'worst case' results for S1 and S2. The potential impacts for S4 in the 'worst case' are approximately equivalent to those for S1 in the 'best case'. The addition of moisture during 
the active aftercare operations period results in the majority of leachate contaminants being flushed out of the landfill via $Q_{e}$ during this period. Therefore, even if the flow volume of leachate via either $Q_{s}$ or $Q_{g}$ increases due to active control loss, the contaminant concentrations in the leachate are so low that the potential impacts of leachate discharges are minimal. This finding indicates that the adoption of accelerated aftercare strategies that incorporate the addition of moisture to the landfill can result in a potentially significant reduction in the potential impacts of landfilling, even if active control systems stop soon after the period of active aftercare operations.

\subsection{The use of life cycle assessment}

Landfill aftercare has previously been evaluated using risk assessment techniques that utilise site-dependant leachate transport models to assess the pollution potential of closed sites, typically focusing on groundwater pollution risk (Laner et al., 2012; Butt et al., 2014) The use of LCA to evaluate landfill aftercare adds an extra dimension to this by considering the potential environmental and human health impacts of leachate emissions via different pathways in the long term. The use of contaminant species-specific LCIA adds further weight by enabling the identification of species that contribute most to the environmental burdens of a site. For example, the LCA results presented here show that the potential impacts of discharged treatment effluents can actually account for a substantial proportion of the potential impacts of landfilling, particularly where active control is well maintained (see Figure 4). This is due to the incomplete treatment of leachate contaminants, particularly $\mathrm{Zn}(\mathrm{II}), \mathrm{Cr}(\mathrm{VI}), \mathrm{As}(\mathrm{III})$, and P, and their discharge to surface water. Similar findings have been reported by previous LCA studies (e.g. Damgaard et al., 2011; Xing et al., 2013). Based on these results, we can surmise that potentially significant environmental benefits could be achieved by improving the treatment efficiencies of key contaminant species. Such information is not provided by standard risk assessment approaches, which typically do not consider the downstream impacts of discharged effluents. LCA can therefore help landfill operators and regulators better understand the environmental performance of a site.

A key issue in the use LCA for evaluating landfill leachate emissions concerns the length of the inventory time horizon applied (Bakas et al., 2015). Whilst LCA recommendations state that the time horizon should ideally be infinite, the choice is ultimately at the discretion of the practitioner, leading to many previous landfill LCA studies to only consider emissions within a 100 year time horizon (e.g. Manfredi and Christensen, 2009; Manfredi et al., 2010; Damgaard et al., 2011). Our results suggest that the selection of such a short time horizon would result in a significant proportion of emissions being unaccounted, which supports the findings of previous researchers (e.g. Doka and Hischier, 2004; Hauschild et al., 2008). If LCA is to be used to provide useful information on the long term impacts of landfilling then a time horizon of 100 years is insufficient. A time horizon of at least 1,000 years was here found necessary to capture the significant proportion of potential impacts. 


\subsection{Mass based LCIA modelling}

A surprising result of the LCIA was that the potential impacts of a fully controlled, 'flushing' landfill were only $\sim 4$ times better than those of a landfill where there were no active controls. The reason for this is likely related to the use of a mass-based LCIA approach, where equal weighting is given to the same mass of a contaminant discharged at low concentrations, even if below Environmental Quality Standard (EQS) concentrations, to that discharged at much higher concentrations. This approach does not consider the physico-chemical conditions of the local environment (e.g. $\mathrm{pH}$, redox potential, or background concentrations), which are influential in contaminant fate modelling (Hellweg et al., 2005; Pizzol et al., 2011; Plouffe et al., 2015). For micro-scale studies of particular landfill sites, the LCA approach could be complimented by the use of risk assessment techniques (Lemming et al., 2012; Schwab et al., 2014).

\subsection{USEtox characterisation factor availability}

The USEtox model, used here to quantify toxicity-related potential impacts, remains in development and LCIA characterisation factors are lacking in two key areas. Firstly, due to a lack of characterisation factors for emissions to groundwater, we approximated such impacts based on the characterisation factors for emissions to freshwater. However, as emissions to groundwater are affected by natural processes, such as attenuation, which can reduce the toxicological potential of contaminant species, it is highly likely that the toxicological impacts of emissions to groundwater are overestimated. Secondly, characterisations factors are not available for many known landfill pollutants, such as dissolved organic carbon and chloride. Consequently, the potential impacts of emissions of these potentially important leachate contaminants could not be quantified.

\subsection{Model simplifications}

The life cycle inventory only included emissions to the aqueous environment and was compiled using a simple mechanistic model (see 2.2). Whilst other, potentially more sophisticated, fate and transport models have been used in the past to evaluate landfill aftercare strategies (e.g. Hellweg et al., 2005; Barlaz et al., 2002; Laner et al., 2012), the approach used here was considered justified due to the proof-of-concept nature of the research. It is, however, acknowledged that this simplistic approach may represent a potential limitation.

\section{Conclusions \& recommendations}

An integrated mechanistic water flow and solute movement model and LCA approach that includes degradation of engineering systems and the new concept of 'active control loss' has here been applied to compare the potential environmental and human health impacts of leachate emissions for four different landfill aftercare scenarios. 
The timing and duration of active control loss during aftercare was found to be a potentially important in terms of the overall impact of landfilling. For the vast majority of active control loss situations, the typical aftercare scenario (i.e. low-permeability capping) resulted in the greatest potential impacts when compared with any of the accelerated aftercare scenarios involving increased infiltration rates. Even where active controls are maintained indefinitely, the typical aftercare scenario resulted in approximately $30-35 \%$ higher potential impacts than the three accelerated aftercare scenarios. This was mainly due to slow but long-term leakage of untreated leachate to groundwater in the typical aftercare scenario.

Following the end of active aftercare operations, the time during which active control must be lost before total potential impacts increase by $5 \%$ (relative to the total potential impacts for the typical aftercare scenario in the 'best case' active control situation) varied from 25 years for the typical aftercare scenario to as high as 8,000 years for the accelerated aftercare scenario with the largest and most sustained initial infiltration rate. For the accelerated aftercare scenarios, a loss of control immediately after the period of active aftercare operations resulted in substantial discharges of contaminants to surface water. However, the potential environmental impacts of such discharges were found to be minor since a substantial proportion of leachate contaminants had already been 'flushed' from the site.

Indefinite loss of active control after the period of active aftercare operations was found to result in only modest increases in potential impacts for all aftercare scenarios. This is due to the substantial base load of potential impacts from the managed leachate flow to effluent that are caused by the incomplete treatment of contaminants and their subsequent discharge to surface water. This highlights a flaw in current mass-based LCIA methods, with concentration only considered extrinsically in background LCIA characterisation models (e.g. USEtox). Nevertheless, we show that the use of LCA can aid landfill operators by identifying opportunities to reduce the environmental impacts of their landfill sites, e.g. by improving the treatment efficiencies of key contaminants.

Based on our findings, the following recommendations are made to LCA practitioners wishing to evaluate the long term potential impacts of landfill leachate emissions:

- Modelling needs to be undertaken over long time horizons (e.g. 10,000 years).

- More sophisticated leachate contaminant fate and transport modelling that includes speciation, partitioning between environmental media, and local physico-chemical conditions (e.g. background concentrations) should be undertaken if leachate emissions are a key focus of the study.

- Toxicity-related LCIA impact factors need to be developed for a wider range of pollutants, including dissolved organic carbon and chloride, as well as specific LCIA impact factors for emissions to groundwater. 


\section{Acknowledgements}

This research was financially supported by the UK Engineering and Physical Sciences Research Council (EPSRC) [Grant EP/I012206/1]. The authors would like to thank Keith Knox and Kerry Rowe for their valuable input in developing the methodology of this research, as well as Jan Gronow and Terry Coleman for their useful feedback on the manuscript.

\section{Data statement}

Relevant data supporting this study are openly available from the University of Southampton repository at http://dx.doi.org/10.5258/SOTON/401426.

\section{References}

Bakas, I., Hauschild, M. Z., Astrup, T. F. and Rosenbaum, R. K. (2015). Preparing the ground for an operational handling of long-term emissions in LCA. International Journal of Life Cycle Assessment, 20, 1444-1455.

Barlaz, M., Bareither, C., Hossain, A., Saquing, J., Messari, I., Benson, C., Tolaymat, T. and Yazdani, R. (2010) Performance of North American bioreactor landfills. II: Chemical and biological characteristics. Journal of Environmental Engineering, 136 (8), 839853.

Barlaz, M. A., Rooker, A. P., Kjeldsen, P., Gabr, M. A. and Borden, R. C. (2002). Critical Evaluation of Factors Required To Terminate the Postclosure Monitoring Period at Solid Waste Landfills. Environmental Science \& Technology, 36, 3457-3464.

Beaven, R.P. (2000) The hydrogeological and geotechnical properties of household waste in relation to sustainable landfilling, $\mathrm{PhD}$ thesis, Queen Mary and Westfield College, University of London.

Beaven, R.P., Knox, K., Gronow, J.R., Hjelmar, O., Greedy, D. and Scharff, H. (2014) A new economic instrument for financing accelerated landfill aftercare. Waste Management, 34 (7), 1191-1198.

Bonaparte, R., Daniel, D. and Koerner, R.M. (2002) Assessment and recommendations for improving the performance of waste containment systems, EPA Report CR-82144801-0. Washington, DC, USA: United States Environmental Protection Agency.

Broun, R. and Sattler, M. (2016) A comparison of greenhouse gas emissions and potential electricity recovery from conventional and bioreactor landfills. Journal of Cleaner Production, 112, 2664-2673.

Burton, S.A.Q., Beaven, R.P. and White, J.K. (2004) The effect of moisture content in controlling landfill gas production and its application to a model for landfill refuse 
decomposition, Proceedings Waste 2004, Stratford-upon-Avon, UK, 22 - 24

September 2004.

Butt, T. E., Gouda, H. M., Baloch, M. I., Paul, P., Javadi, A. A. and Alam, A. (2014). Literature review of baseline study for risk analysis - the landfill leachate case. Environment International, 63, 149-162.

Christensen, T. H., Manfredi, S. and Kjeldsen, P. (2011). Landfilling: environmental issues. In: Christensen, T. H. (ed.) Solid waste technology \& management. Chichester, UK: Blackwell Publishing Ptd.

Clavreul, J., Guyonnet, D. and Christensen, T.H. (2012) Quantifying uncertainty in LCAmodelling of waste management systems. Waste Management, 32 (12), 2482-2495.

Clift, R., Doig, A. and Finnveden, G. (2000) The application of life cycle assessment to integrated solid waste management. Part 1 - methodology. Process Safety and Environmental Protection, 78 (4), 279-287.

Damgaard, A., Manfredi, S., Merrild, H., Stensoe, S. and Christensen, T.H. (2011) LCA and economic evaluation of landfill leachate and gas technologies. Waste Management, 31 (7), 1532-1541.

Demetracopoulos, A.C., Sehayek, L. and Erdogan, H. (1986) Modeling leachate production from municipal landfills. Journal of the Environmental Engineering Division, 112, 849-866.

Doka, G. (2009) Life cycle inventories of waste treatment services. ecoinvent report No. 13. Dübendorf, Switzerland: Swiss Centre for Life Cycle Inventories.

Doka, G. and Hischier, R. (2004) Waste treatment and assessment of long-term emissions. The International Journal of Life Cycle Assessment, 10 (1), 77-84.

Drury, D., Hall, D. and Dowle, J. (2003) The development of LandSim 2.5. NCWCLC report GW/03/09. Solihull, UK: Environment Agency.

EA (2007) Guidance for the treatment of landfill leachate. London, UK: Environment Agency.

Ekvall, T., Assefa, G., Bjorklund, A., Eriksson, O. and Finnveden, G. (2007) What life-cycle asessment does and does not do in assessments of waste management. Waste Management, 27 (8), 989-996.

European Commission (1999) Council Directive 1999/31/EC of 26 April 1999 on the landfill of waste. Official Journal of the European Communities, L 182, 1-19. 
Fellner, J., Döberl, G., Allgaier, G. and Brunner, P. H. (2009) Comparing field investigations with laboratory models to predict landfill leachate emissions. Waste Management, 29 (6), 1844-1851.

Gentil, E.C., Damgaard, A., Hauschild, M., Finnveden, G., Eriksson, O., Thorneloe, S., Kaplan, P.O., Barlaz, M., Muller, O. and Matsui, Y. (2010) Models for waste Life Cycle Assessment: Review of technical assumptions. Waste Management, 30 (12), 2636-2648.

Giroud, J.P., Badu-Tweneboah, L. and Soderman, K.L. (1997) Comparison of leachate flow through compacted clay liners and geosynthetic clay liners in landfill liner systems. Geosynthetics International, 4 (2-3), 391-431.

Goedkoop, M.J., Heijungs, R., Huijbreghts, M., De Schryver, A., Struijs, J. and van Zelm, R. (2013) ReCiPe 2008 - A life cycle assessment method which comprises harmonised category indicators at the midpoint and the endpoint level. Amsterdam, the Netherlands: Ruimte En Milieu Ministerie Van Volkshuisvesting Ruimtelijke Ordening En Milieubeheer.

Golder Associates (2008) Report on fail-safe engineering modelling for landfill closure WR0304 - final report. London, UK: Department for Environment Food \& Rural Affairs.

Güereca, L.P., Gassó, S., Baldasano, J.M. and Jiménez-Guerrero, P. (2006) Life cycle assessment of two biowaste management systems for Barcelona, Spain. Resources, Conservation and Recycling, 49 (1), 32-48.

Hall, D.H., Drury, D., Gronow, J.R., Rosevear, A., Pollard, S.J.T. and Smith, R. (2006a) Estimating pollutant removal requirements for landfills in the UK: I. Benchmark study and characteristics of waste treatment technologies. Environmental Technology, 27 (12), 1309-1321.

Hall, D.H., Drury, D., Gronow, J.R., Rosevear, A., Pollard, S.J.T. and Smith, R. (2006b) Estimating pollutant removal requirements for landfills in the UK: II. Model development. Environmental Technology, 27 (12), 1323-1333.

Hauschild, M., Goedkoop, M., Guinée, J., Heijungs, R., Huijbregts, M., Jolliet, O., Margni, M., De Schryver, A., Humbert, S., Laurent, A., Sala, S. and Pant, R. (2013) Identifying best existing practice for characterization modeling in life cycle impact assessment. The International Journal of Life Cycle Assessment, 18 (3), 683-697.

Hauschild, M., Olsen, S.I., Hansen, E. and Schmidt, A. (2008) Gone...but not awayaddressing the problem of long-term impacts from landfills in LCA. The International Journal of Life Cycle Assessment, 13 (7), 547-554. 
Hellweg, S., Fischer, U., Hofstetter, T.B. and Hungerbühler, K. (2005) Site-dependent fate assessment in LCA: transport of heavy metals in soil. Journal of Cleaner Production, 13 (4), 341-361.

Hjelmar O., van der Sloot H.A., Guyonnet D., Rietra R.P.J.J., Brun A. and Hall D.H. (2001) Development of acceptance criteria for landfilling of waste: an approach based on impact modelling and scenario calculations. In: Proceedings Eighth Sardinia International Waste Management and Landfill Symposium. CISA, Cagliari, 711-721.

Hjelmar, O., van der Sloot, H.A., Comans, R.N.J. and Wahlström, M. (2013) EoW criteria for waste-derived aggregates. Waste and Biomass Valorization, 4 (4), 809-819.

Hoornweg, D. and Bhada-Tata (2012) What a waste - a global review of solid waste management. Washington, DC, USA: World Bank.

ISO (2006a) ISO 14040:2006 Environmental management - Life cycle assessment Principles and framework. Geneva, Switzerland: International Organization for Standardization.

ISO (2006b) ISO 14044:2006 Environmental management - Life cycle assessment Requirements and guidelines. Geneva, Switzerland: International Organization for Standardization.

JRC-IES (2011) ILCD handbook: Recommendations for life cycle impact assessment in the European context. Luxemburg: European Commission - Joint Research Centre Institute for Environment and Sustainability.

Kattenberg, W.J., van der Sloot, H.A. and Heimovaara, T.J. (2013) New Dutch legislation to allow research of natural biodegradation at landfills, Proceedings Sardinia 2013, Fourteenth International Waste Management and Landfill Symposium, S. Margherita di Pula, Cagliari, Sardinia, Italy, 30 September - 4 October.

Kim, J., Yang, Y., Bae, J. and Suh, S. (2013) The importance of normalization references in interpreting Life Cycle Assessment results. Journal of Industrial Ecology, 17 (3), 385395.

Knox, K. (1990) The relationship between leachate and gas. Proceedings International Conference Landfil Gas: Energy and Environment Conference. Didcot, UK: Energy Technology Support Unit (ETSU), 367-386.

Knox, K., Braithwaite, P., Caine, M. and Croft, B. (2005) Brogborough landfill test cell: the final chapter. A study of landfill completion in relation to final storage quality (FSQ) criteria Proceedings of Sardinia 2005, Tenth International Waste Management and Landfill Symposium. Cagliari, Italy. 
Kosson D.S., van der Sloot, H.A., Sanchez, F. and Garrabrants, A.C. (2004) An integrated framework for evaluating leaching in waste management and utilization of secondary materials, Environmental Engineering Science 19 (3), 159-204.

Laner, D., Crest, M., Scharff, H., Morris, J. W. and Barlaz, M. A. (2012). A review of approaches for the long-term management of municipal solid waste landfills. Waste Management, 32, 498-512.

Laurent, A., Hauschild, M.Z., Golsteijn, L., Simas, M., Fontes, J. and Wood, R. (2013) Deliverable 5.2 Normalisation factors for environmental, economic and socioeconomic indicators. Copenhagen, Denmark: Prosuite. Available from: http://prosuite.org/c/document_library/get_file?uuid=750ef6d0-4e9d-4a00-913c$3 f 4 c f d 632782 \&$ groupId $=12772$.

Lemming, G., Chambon, J. C., Binning, P. J. and Bjerg, P. L. (2012). Is there an environmental benefit from remediation of a contaminated site? Combined assessments of the risk reduction and life cycle impact of remediation. Journal of Environmental Management, 112, 392-403.

Manfredi, S. and Christensen, T. (2009) Environmental assessment of solid waste landfilling technologies by means of LCA-modeling. Waste Management, 29 (1), 32-43.

Manfredi, S., Tonini, D. and Christensen, T.H. (2010) Contribution of individual waste fractions to the environmental impacts from landfilling of municipal solid waste. Waste Management, 30 (3), 433-440.

Meima, J.A., Naranjo, N.M. and Haarstrick, A. (2008) Sensitivity analysis and literature review of parameters controlling local biodegradation processes in municipal solid waste landfills. Waste Management, 28 (5), 904-918.

Ministry of the Environment (2008) Landfilling sites. Ontario Regulation 232/98 (as amended). 232/98. Ministry of the Environment. Government of Ontario, Toronto.

Pizzol, M., Christensen, P., Schmidt, J. and Thomsen, M. (2011) Eco-toxicological impact of "metals" on the aquatic and terrestrial ecosystem: A comparison between eight different methodologies for Life Cycle Impact Assessment (LCIA). Journal of Cleaner Production, 19 (6-7), 687-698.

Plouffe, G., Bulle, C. and Deschênes, L. (2015) Case study: taking zinc speciation into account in terrestrial ecotoxicity considerably impacts life cycle assessment results. Journal of Cleaner Production, 108, 1002-1008.

Pommier, S., Chenu, D., Quintard, M. and Lefebvre, X. (2007) A logistic model for the prediction of the influence of water on the solid waste methanization in landfills. Biotechnology and Bioengineering, 97 (3), 473-482. 
Reitzel, S., Farquahar, G. and McBean, E. (1992) Temporal characterisation of Municipal Solid Waste Leachate. Canadian Journal of Civil Engineering, August edition, 668679.

Robinson, H. and Knox, K. (2001) Pollution inventory discharges to sewer or surface waters from landfill leachates. Bristol, UK: Environment Agency.

Rosenbaum, R., Bachmann, T., Gold, L., Huijbregts, M.J., Jolliet, O., Juraske, R., Koehler, A., Larsen, H., MacLeod, M., Margni, M., McKone, T., Payet, J., Schuhmacher, M., van de Meent, D. and Hauschild, M. (2008) USEtox - the UNEP-SETAC toxicity model: recommended characterisation factors for human toxicity and freshwater ecotoxicity in life cycle impact assessment. The International Journal of Life Cycle Assessment, 13 (7), 532-546.

Rosqvist, N. H., Dollar, L. H. and Fourie, A. B., Preferential flow in municipal solid waste and implications for long-term leachate quality: valuation of laboratory-scale experiments. Waste Management \& Research, 23 (4), 2005, 367-380.

Rowe, R.K. (1991) Contaminant impact assessment and the contaminant lifespan of landfills. Canadian Journal of Civil Engineering, 18 (2), 244-253.

Rowe, K. (2005) Long-term performance of contaminant barrier systems. Geotechnique, 55 (9), 631-678.

Rowe, R.K., Islam, M.Z., Brachman, R.W.I., Arnepalli, D.N. and Ragab Ewais, A. (2010) Antioxidant depletion from a high density polyethylene geomembrane under simulated landfill conditions. Journal of Geotechnical and Geoenvironmental Engineering, 136 (7), 930-939.

Scharff, H., van Zomeren, A. and van der Sloot, H.A. (2011) Landfill sustainability and aftercare completion criteria. Waste Management \& Research, 29 (1), 30-40.

Schwab, O., Bayer, P., Juraske, R., Verones, F. and Hellweg, S. (2014) Beyond the material grave: Life Cycle Impact Assessment of leaching from secondary materials in road and earth constructions. Waste Management, 34 (10), 1884-1896.

Shafer, M.M., Overdier, J.T. and Armstong, D.E. (1998) Removal, partitioning, and fate of silver and other metals in wastewater treatment plants and effluent-receiving streams. Environmental Toxicology and Chemistry, 17 (4), 630-641.

Stranddorf, H.K., Hoffmann, L. and Schmidt, A. (2005) Impact categories, normalisation and weighting in LCA. Copenhagen, Denmark: Danish Ministry of the Environment.

Straub, W.A. and Lynch, D.R. (1982) Models of landfill leaching: moisture flow and inorganic strength. Journal of Environmental Engineering, 108, 231-250. 
Thomas, B. and McDougall, F. (2005) International expert group on life cycle assessment for integrated waste management. Journal of Cleaner Production, 13 (3), 321-326.

Townsend, T.G., Miller, W.L., Lee, H.-J. and Earle, J.F.K. (1996) Acceleration of landfill stabilization using leachate recycle. Journal of Environmental Engineering, 122 (4), 263-268.

Turner, D.A., Williams, I.D. and Kemp, S. (2016) Combined material flow analysis and life cycle assessment as a support tool for solid waste management decision making. Journal of Cleaner Production, 129, 234-248.

United Nations (1987) Our Common Future - the Brundtland Report. Oxford, UK: Oxford University Press.

US EPA (1999) Understanding variation in partition coefficient, Kd, values. Washington, DC, USA: United States Environmental Protection Agency.

US EPA (2011) Background information document for life-cycle inventory landfill process model. Durham, NC, USA: United States Environmental Protection Agency.

Winkler, J. and Bilitewski, B. (2007) Comparative evaluation of life cycle assessment models for solid waste management. Waste Management, 27 (8), 1021-1031.

Woodman, N.D., Beaven, R.P. and Barker, J.A. (2007) Critique of landfill flushing using exponential models IN: Haarstrick, A. and Reichel, T. (eds.) Landfill modelling. Padova, Italy: CISA.

Woodman, N.D., Rees-White, T.C., Stringfellow, A., Beaven, R.P. and Hudson, A.P. (2014) Multiple-tracer tests for contaminant transport process identification in saturated municipal solid waste. Waste Management, 38, 250-262.

Xing, W., Lu, W., Zhao, Y., Zhang, X., Deng, W. and Christensen, T.H. (2013) Environmental impact assessment of leachate recirculation in landfill of municipal solid waste by comparing with evaporation and discharge (EASEWASTE). Waste Management, 33 (2), 382-389. 